Article

\title{
Ajmalicine and Reserpine: Indole Alkaloids as Multi-Target Directed Ligands Towards Factors Implicated in Alzheimer's Disease
}

\author{
Priya Kashyap ${ }^{1}$, Vivekanandan Kalaiselvan ${ }^{2}$, Robin Kumar ${ }^{2}$ and Suresh Kumar ${ }^{1, *}$ \\ 1 University School of Biotechnology, Guru Gobind Singh Indraprastha University, Dwarka, Sector 16C, \\ New Delhi 110075, India; girlnamedpia@gmail.com \\ 2 Indian Pharmacopoeia Commission, Pharmacovigilance Laboratory, Sector 23, Raj Nagar, Ghaziabad, \\ Uttar Pradesh-201002, India; kalaiselvan.ipc@gov.in (V.K.); robinkumar.ipc@gov.in (R.K.) \\ * Correspondence: sureshkumar@ipu.ac.in
}

Received: 20 February 2020; Accepted: 14 March 2020; Published: 1 April 2020

\begin{abstract}
Alzheimer's disease (AD) is a multifactorial disorder characterized by exponential loss of memory and cognitive deficit involving several disease modifying targets (amyloid beta, beta-secretase, monoaminoxidase- $\mathrm{B}$, and cholinesterase). The present study explores multi-target directed ligand approach using secondary metabolite reserpine (RES) and ajmalicine (AJM) obtained from Rauwolfia serpentina roots. Novel LCMS and HPLC methods were developed for identification and quantification of reserpine and ajmalicine. In vitro enzyme inhibition assays were performed to evaluate anti-cholinesterase, $\beta$-site amyloid cleaving enzyme (BACE-1) inhibition and monoamine oxidase-B (MAO-B) inhibition, further analyzed with in silico analysis. Anti-amyloidogenic potential was studied using anti-aggregation studies along with TEM and circular dichroism (CD) analysis. In vitro neuroprotective potential against $A \beta$ toxicity and anti-oxidative stress was demonstrated using PC12 cell cultures. Reserpine is a more potent dual cholinesterase inhibitor than ajmalicine $\left(\mathrm{IC}_{50}\right.$ values of $1.7 \mu \mathrm{M}(\mathrm{AChE})$ and $2.8 \mu \mathrm{M}(\mathrm{BuChE})$ ). The anti-aggregation activity of reserpine $(68 \%)$ was more than ajmalicine (56\%). Both compounds demonstrated neuroprotective activity against $\mathrm{A} \beta 42(92 \%)$ and $\mathrm{H}_{2} \mathrm{O}_{2}(93 \%)$ induced toxicity in PC12 cells against controls. Phytocompounds also inhibited MAO-B and BACE-1 enzymes in concentration dependent manner. Molecular docking studies indicated the strong binding of compounds to the catalytic site of targets. This novel study demonstrated that reserpine and ajmalicine as a multi-target directed ligand that have disease modifying potential for amelioration of $\mathrm{AD}$.
\end{abstract}

Keywords: Alzheimer's disease; reserpine; ajmalicine; multi target directed ligand; A $\beta$; BACE-1; MAO-B; molecular docking; rauwolfia serpentina

\section{Introduction}

Alzheimer's disease (AD) is the most common neurodegenerative disease characterized by memory loss and cognitive decline. The increasing disease burden is estimated to double every 20 years according to the World Alzheimer Report 2016 [1]. The worldwide economic burden is approximately US $\$ 800$ billion per year [2]. AD is a complex multifactorial disease involving several identified targets. According to amyloid hypothesis, $\beta$-site amyloid cleaving enzyme (BACE-1) cleaves amyloid precursor protein (APP) at its extracellular site followed by intra-membrane cleavage by $\gamma$-secretase releasing insoluble $\mathrm{A} \beta$ peptides ( $\mathrm{A} \beta 40$ or $\mathrm{A} \beta 42$ residues) causing extracellular plaque formation in amyloidogenic pathway of $\mathrm{AD}$. $\mathrm{A} \beta 42$ aggregation also induces oxidative stress in the central nervous system (CNS), which creates a feedback loop accelerating $A \beta 42$ fibrillation further [3]. Another affected target in $\mathrm{AD}$ is cholinergic neurotransmission in $\mathrm{CNS}$ due to reduced choline neurotransmitter 
secretion [4]. Despite advanced AD researches, the current treatment strategies for AD mainly deal with providing symptomatic relief by improving cholinergic neurotransmission in CNS. Currently approved drugs for AD includes anti-cholinesterase, such as donepezil, galanthamine, and NMDA ( $N$-methyl-D-aspartate) antagonists (memantine) [5]. At present, no disease modifying drugs are available for the treatment of $A D$. Due to multifactorial nature of $A D$, several therapeutic strategies were devised that include prevention and inhibition of $A \beta 42$ aggregation and reducing oxidative stress in CNS [6]. In view of these, multiple targets were identified in AD such as A $\beta 42$ peptide, acetylcholinesterase (AChE), butyrylcholinesterase (BuChE), BACE-1, monoamine oxidase-B (MAO-B), and reactive oxygen species (ROS). The current strategy involved a multi-target directed ligand (MTDL) approach where the drug molecule(s) can target key enzymes along with disease causing peptides involved in $\mathrm{AD}$, simultaneously, with single or multiple compounds that might be useful in providing therapeutic relief to $\mathrm{AD}$ patients. The $\mathrm{PC} 12$ cells are used as in vitro model systems to induce toxicity by $\mathrm{A} \beta$ fibrils or $\mathrm{H}_{2} \mathrm{O}_{2}[7,8]$.

Rauwolfia serpentina has been mentioned in ancient Ayurvedic texts for its nootropic activity and treatment of various CNS disorders associated with psychosis, schizophrenia, insanity, insomnia, and epilepsy [9]. Previous studies reported several phyto-constituents present in R. serpentina extract such as yohimbine, ajmaline, reserpine, and serpentine [10]. The major secondary metabolites in the current study, are indole alkaloids; reserpine (RES) and ajmalicine (AJM). Reserpine previously reported having antihypertensive properties that can also cross blood brain barrier because of its lipid solubility nature, whereas ajmalicine has also been reported for its antihypertensive activity $[11,12]$ The objective of the current study is to elucidate the multi-target drug ligand potential of reserpine and ajmalicine. The selected compounds demonstrated to bind with AD targets and imparts anti-cholinesterase, anti-amyloidogenic, antioxidant, and neuroprotective activity along with anti-BACE-1 and anti-MAO B potential.

\section{Results}

\subsection{Metabolites Identification Using UHPLC-QTOF/MS}

UHPLC-QTOF MS was used for metabolite analysis of $R$. serpentina hydro-alcoholic extract. Crude extract was analyzed for masses present, in both electron spray ionization (ESI) positive and ESI negative mode. The masses that were detected consistently as $[\mathrm{M}+\mathrm{H}]$ and $[\mathrm{M}-\mathrm{H}]$ ions were identified and matched with literature database and identity of metabolites was established (Table 1). ESI positive mode gave better metabolite profiling; as it detected maximum number of constituents therefore further analysis was carried out in ESI positive mode. There were few unmatched and thus unidentified masses, which consistently appeared in trace quantities in LCMS runs.

Table 1. List of identified compounds in electron spray ionization (ESI) positive mode of ionization from $R$. serepentina hydroalcoholic extract by UHPLC-QTOF analysis.

\begin{tabular}{cccccc}
\hline Peak No. & Compound Name & Formula & $\begin{array}{c}\text { Monoisotopic } \\
\text { Mass }\end{array}$ & $\begin{array}{c}\text { Retention } \\
\text { Time (min) }\end{array}$ & $\begin{array}{c}m+z \\
\text { Values }\end{array}$ \\
\hline 1 & Behenic Acid & $\mathrm{C}_{22} \mathrm{H}_{44} \mathrm{O}_{2}$ & 340.592 & 5.7 & 341.578 \\
2 & Sarpagine & $\mathrm{C}_{19} \mathrm{H}_{22} \mathrm{~N}_{2} \mathrm{O}_{2}$ & 310.168 & 8.5 & 311.168 \\
3 & Ajmaline & $\mathrm{C}_{20} \mathrm{H}_{26} \mathrm{~N}_{2} \mathrm{O}_{2}$ & 326.199 & 12.9 & 327.199 \\
4 & Ajmalicine & $\mathrm{C}_{21} \mathrm{H}_{24} \mathrm{~N}_{2} \mathrm{O}_{3}$ & 352.179 & 13.4 & 353.177 \\
5 & Yohimbine & $\mathrm{C}_{21} \mathrm{H}_{26} \mathrm{~N}_{2} \mathrm{O}_{3}$ & 354.194 & 13.7 & 355.196 \\
6 & Serpentine & $\mathrm{C}_{21} \mathrm{H}_{20} \mathrm{~N}_{2} \mathrm{O}_{3}$ & 348.147 & 14.6 & 349.148 \\
7 & Reserpine & $\mathrm{C}_{33} \mathrm{H}_{40} \mathrm{~N}_{2} \mathrm{O}_{9}$ & 608.273 & 15.3 & 609.271 \\
8 & Deserpedine & $\mathrm{C}_{32} \mathrm{H}_{38} \mathrm{~N}_{2} \mathrm{O}_{8}$ & 578.263 & 15.9 & 579.263 \\
9 & Reserpiline & $\mathrm{C}_{23} \mathrm{H}_{28} \mathrm{~N}_{2} \mathrm{O}_{5}$ & 412.2 & 16.3 & 413.202 \\
\hline
\end{tabular}


Table 1. Cont.

\begin{tabular}{cccccc}
\hline Peak No. & Compound Name & Formula & $\begin{array}{c}\text { Monoisotopic } \\
\text { Mass }\end{array}$ & $\begin{array}{c}\text { Retention } \\
\text { Time (min) }\end{array}$ & $\begin{array}{c}m+z \\
\text { Values }\end{array}$ \\
\hline 10 & Alpha or Beta Amyrin & $\mathrm{C}_{30} \mathrm{H}_{50} \mathrm{O}$ & 426.291 & 18.6 & 427.292 \\
11 & Indobine & $\mathrm{C}_{11} \mathrm{H}_{11} \mathrm{NO}_{2}$ & 119.073 & 19.2 & 120.083 \\
12 & Rutin & $\mathrm{C}_{27} \mathrm{H}_{30} \mathrm{O}_{16}$ & 611.52 & 20.6 & 612.521 \\
8 & Unknown_RS1 & & & 15.9 & 290.264 \\
9 & Unknown_RS2 & & & 16.3 & 653.239 \\
11 & Unknown_RS3 & & & 19.2 & 381.288 \\
13 & Unknown_RS4 & & & 20.6 & 685.422 \\
\hline
\end{tabular}

The individual peaks of chromatogram were resolved to the presence of a single metabolite, majorly proving the efficacy of the novel LCMS method developed (Figure 1). There were some trace impurity peaks present in the solvent (methanol blank) but it was ensured that these masses did not interfere with elution or profile of the desired metabolites (Figure 1A).

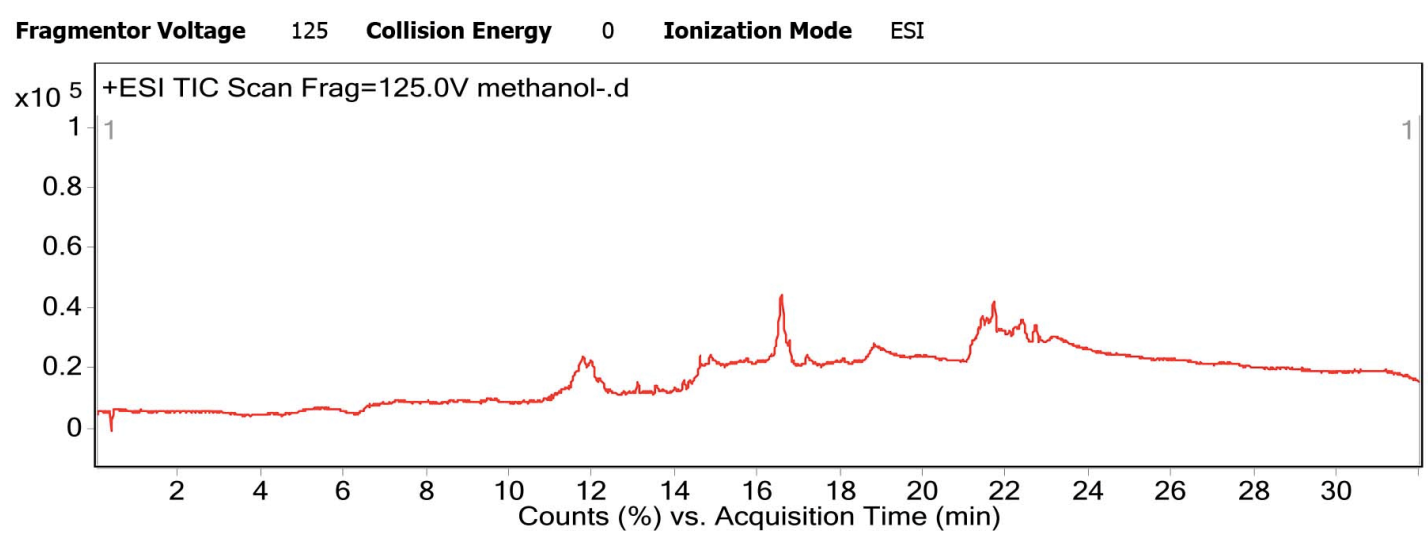

A

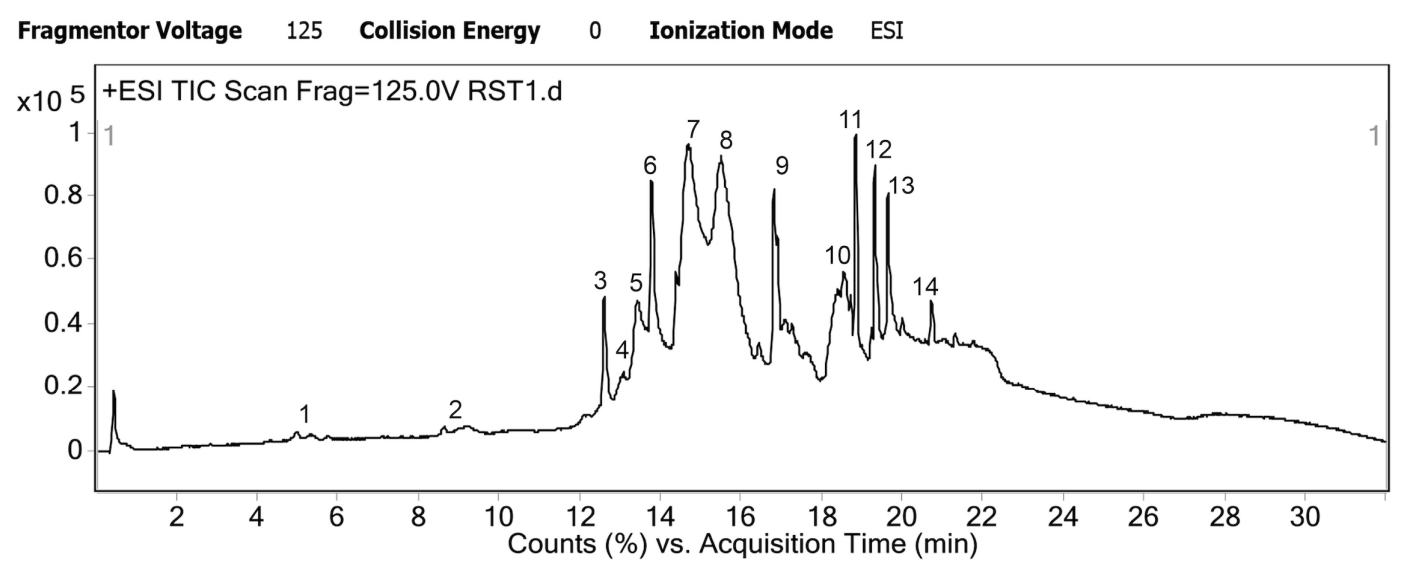

B

Figure 1. Total ion chromatogram generated by Agilent 6520 UHPLC-QTOF instrument and mass hunter software; (A) methanol blank chromatogram; (B) Hydroalcoholic root extract of $R$. serepentina chromatogram, $n=4$ individual LCMS runs. 
The total mass spectrogram (Figure 2) reported high counts of up to $5 \times 10^{6}$ for RES and $2.5 \times 10^{6}$ for AJM. Similarly, RES and AJM were found to be the major phytoconstituents present in $R$. serpentina extract with chromatographic peak area of $19 \%$ and $6 \%$, respectively.

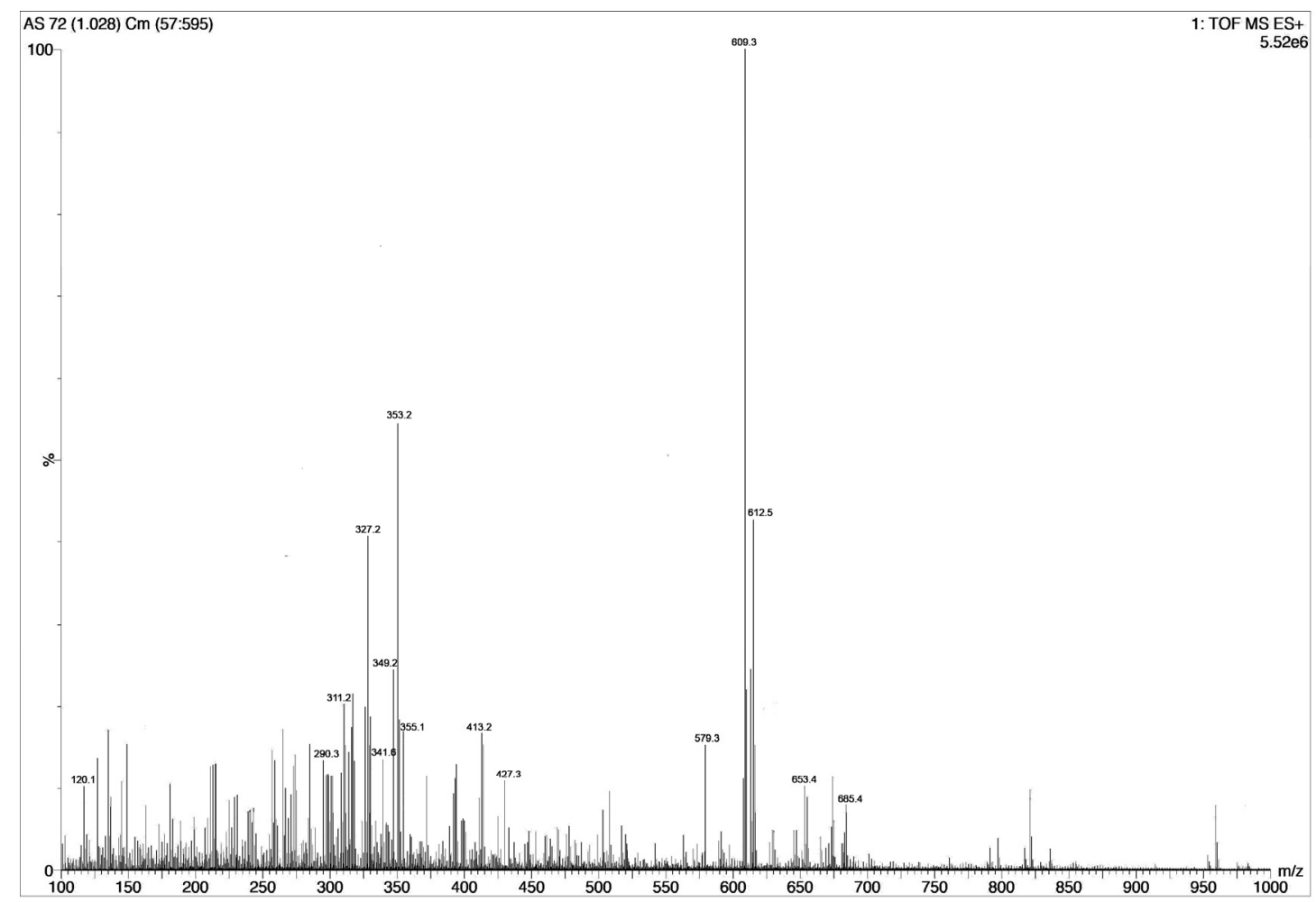

Figure 2. Total mass spectrogram of $R$. serpentina extract in positive mode ESI showing peaks of masses present. Highest $m / z 609$ reflects reserpine and $m / z 353$ reflects ajmalicine presence, $n=4$ individual LCMS runs.

\subsection{Reverse phase HPLC Method Development and Validation for RES and AJM Quantification}

RES and AJM identified from LCMS were quantified using commercially purchased standards. A novel reproducible reverse phase HPLC (RP-HPLC) method for sensitive and rapid detection (or quantification) of RES and AJM was optimized for each, using economic solvents. The methods were validated according to "International Council for Harmonisation (ICH) of technical requirements for pharmaceuticals for human use" for stability, linearity, precision, limit of detection (LOD), and limit of quantification (LOQ) levels (Table 2) [13].

Table 2. Characteristics of reverse phase HPLC (RP-HPLC) method development and validation for reserpine (RES) and ajmalicine (AJM).

\begin{tabular}{ccccccc}
\hline $\begin{array}{c}\text { Indole } \\
\text { Alkaloids }\end{array}$ & $\mathbf{t}_{\mathbf{R}}{ }^{*}(\mathbf{m i n})$ & $\begin{array}{c}\text { Peak } \\
\text { Asymmetry }\end{array}$ & RSD (\%) & $\begin{array}{c}\text { S/N LOD } \\
(\mathbf{p p m})\end{array}$ & $\begin{array}{c}\text { S/N LOQ } \\
(\mathbf{p p m})\end{array}$ & $\begin{array}{c}\text { Linear Regression } \\
\text { Equation }(\mathbf{Y}=\mathbf{A X}+\mathbf{C})\end{array}$ \\
\hline Ajmalicine & $6.1 \pm 0.2$ & 0.91 & 2.3 & 3.7 & 10.5 & $\begin{array}{c}\mathrm{y}=1.5808 \times+0.0495 \\
\mathrm{R}^{2}=0.99984 \\
\mathrm{y}\end{array}$ \\
Reserpine & $5.3 \pm 0.1$ & 0.94 & 1.8 & 2.82 & 9.76 & $\begin{array}{c}\mathrm{y}=130306 \times 5 \\
\mathrm{R}^{2}=0.99998\end{array}$ \\
\hline
\end{tabular}

Peak asymmetry should be around one; $\mathrm{S} / \mathrm{N}$ — signal to noise ratio; ppm—parts per million; RSD—relative standard deviation; and $n=6$ repeated analysis, ${ }^{*} t_{R}$-retention time represented as mean $\pm \mathrm{SD}$.

The calibration curve was plotted between absorbance and different concentrations (0.5-3.5 ppm) of test compound and linear regression equation was obtained. A correlation coefficient $\left(R^{2}\right)$ greater than 0.999 indicates good linearity thus the results showed an excellent correlation exists between the 
peak area and respective concentration of the compound (RES and AJM). Peak asymmetry greater than ' 1 ' indicates peak tailing and less than ' 1 ' indicates peak fronting. In the current study, both the methods developed have their peak asymmetry ratio around 1 , which is a good measure for peak shape. Relative standard deviation (RSD) determination gives a validation for method precision. The RSD percentages for both the methods are low (RSD $<3 \%$ ) therefore the RP-HPLC method precision is good. LOD and LOQ are calculated from signal-to-noise (S/N) ratio in multiples of 3 and 10, respectively. As a measure of sensitive method development, it was found that as minimum as $2.8 \mathrm{ppm}$ for RES and $3.7 \mathrm{ppm}$ for AJM could be successfully detected in the sample. Moreover, a least amount of $9.76 \mathrm{ppm}$ for RES and $10.5 \mathrm{ppm}$ for AJM could be successfully quantified in the sample using the developed method.

After successful RP-HPLC method development, respective compounds were quantified in $R$. serpentina extract. With six injections of standard, three individual injections of samples were chromatographed through the system. Figure 3 shows RES standard peak at $5.3 \mathrm{~min}$ with area $81.1 \mathrm{mAU} / \mathrm{min}$ alongside RES peak present in R. serpentina extract with area $13.9 \mathrm{mAU} / \mathrm{min}$. RES amount was quantified as $15.42 \% w / w$ in $R$. serpentina extract.

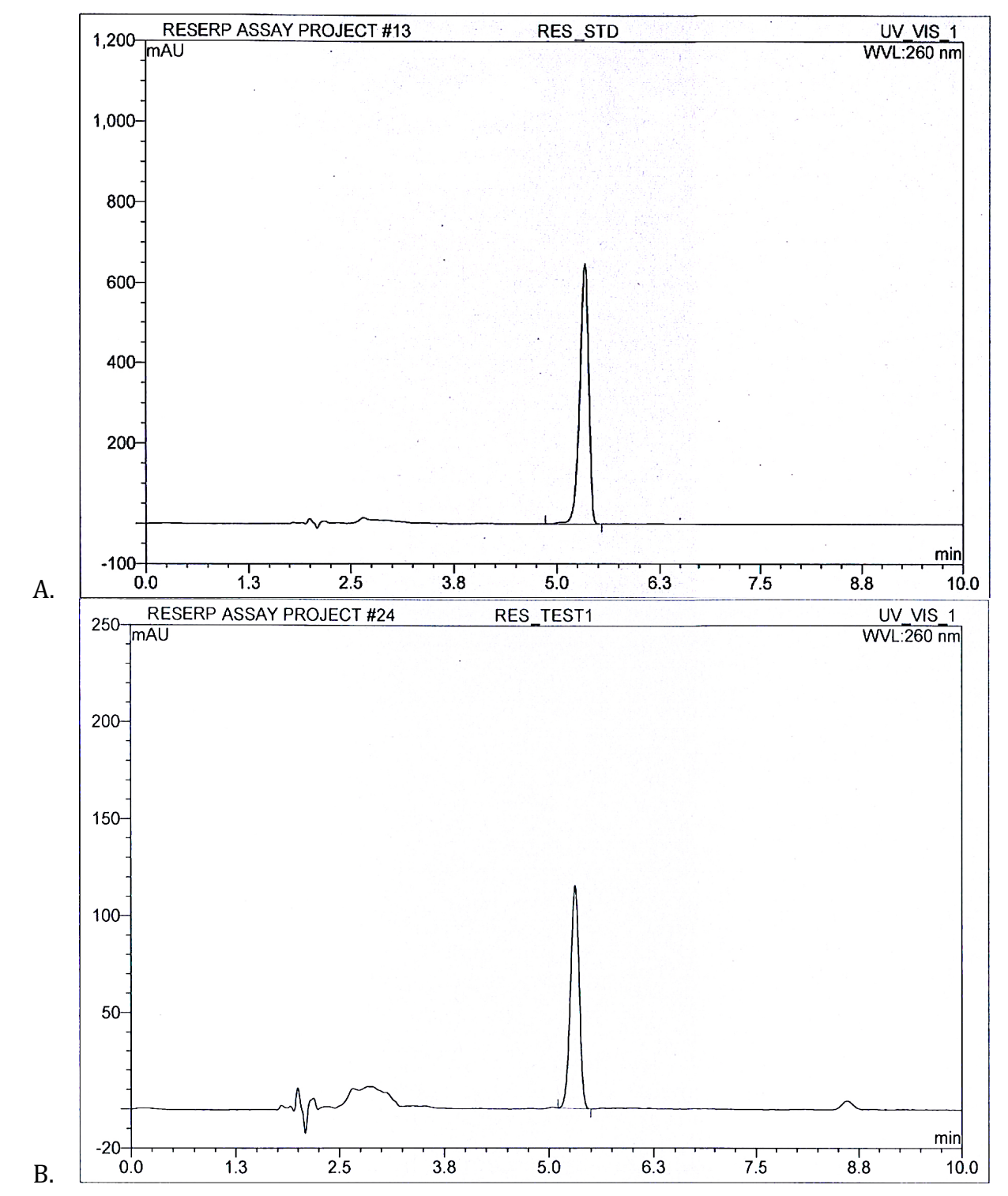

Figure 3. (A) RES standard peak (B) R. serpentina test extract resolved peaks at 5.3 min for RES quantification analysis using developed RP-HPLC method at $260 \mathrm{~nm}$. 
The area under curve for AJM standard peak at 6 min was determined to be $40.9 \mathrm{mAU} / \mathrm{min}$ while for AJM present in R. serpentina extract the area was calculated to be $0.52 \mathrm{mAU} / \mathrm{min}$ by Chromeleon 6.8 chromatography data system software (Figure 4). Thus, quantity of AJM was calculated to be $1.08 \%$ $w / w$ in R. serpentina extract.

A.
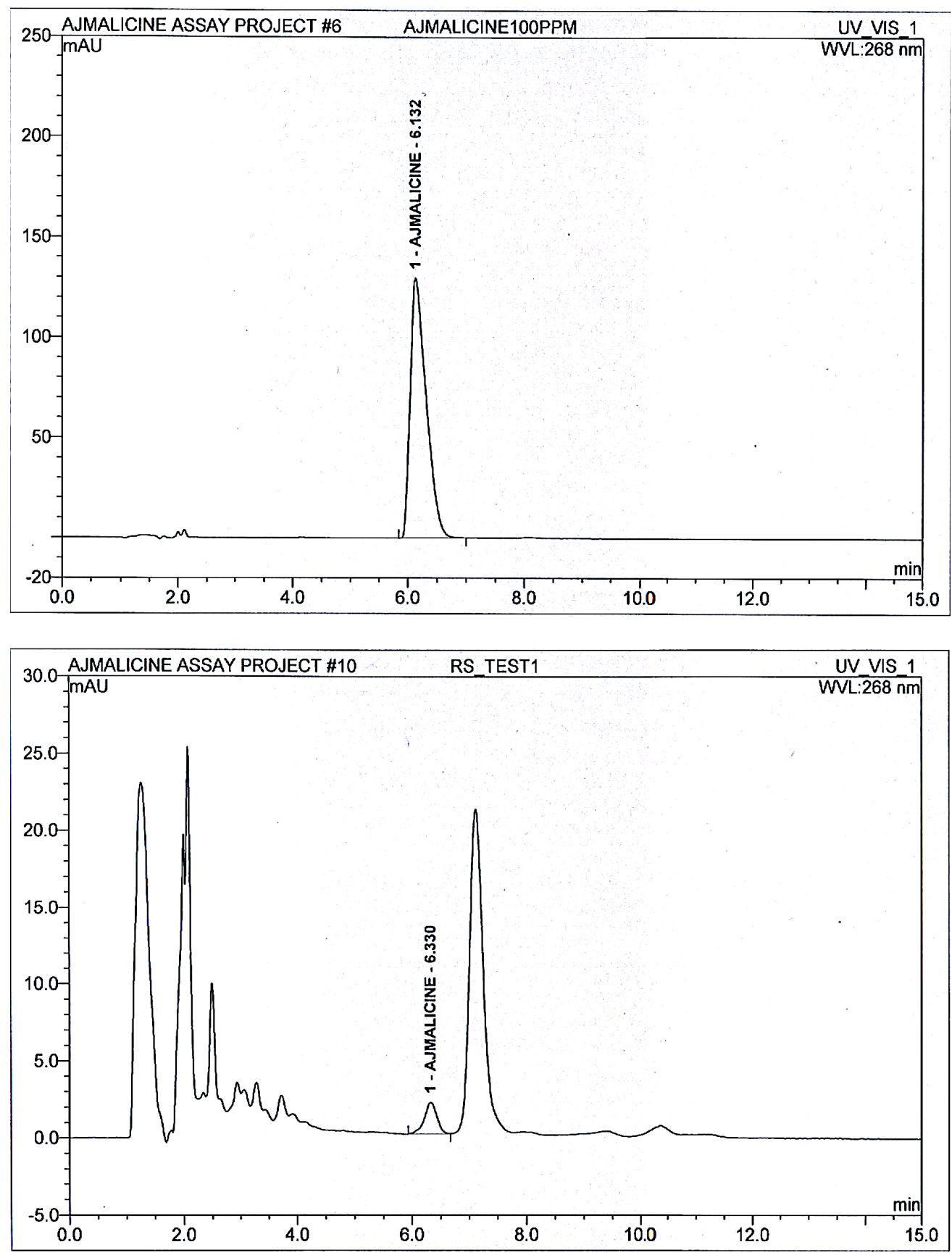

Figure 4. (A) Standard peak (B) R. serpentina test extract resolved peaks at $6.0 \mathrm{~min}$ and $6.3 \mathrm{~min}$, respectively, for AJM quantification analysis using developed RP-HPLC method at $268 \mathrm{~nm}$.

\subsection{Anti-Amyloidogenic Effect of RES and AJM}

Amyloidogenesis involves aggregation of $A \beta$ monomers into oligomers and proto-fibrils that leads to formation of plaques in CNS. The anti-aggregation potential of RES and AJM was analyzed through thioflavin T (ThT) fluorescence assay along with evaluation of red shift in Congo red (CR) dye binding assay. ThT probe gives bright fluorescence upon binding exclusively to A $\beta 42$ proto-fibrils 
at $480 \mathrm{~nm}$ (emission) whereas free ThT quenches at the same excitation wavelength $(450 \mathrm{~nm})$, which makes it the most widely used probe against amyloid fibril detection. RES and AJM significantly inhibited the formation of $A \beta 42$ fibrils in concentration dependent manner (11-44 $\mu \mathrm{M})$, with $69 \%$ inhibition of fluorescence by RES (at $44 \mu \mathrm{M}$ ) (Figure 5) as compared to control sample (A $\beta 42$ only). AJM and hydro-alcoholic root extract of R. serpentina demonstrated inhibition of aggregation ( $57 \%$ at $44 \mu \mathrm{M})$ and $(51 \%$ at $100 \mu \mathrm{g} / \mathrm{mL}$ ), respectively, as compared to control samples (A $\beta 42$ only). An $85 \%$ inhibition of fluorescence was observed when $A \beta 42$ incubated with tannic acid (positive control). The results indicate statistically significant anti-aggregation effect of RES and AJM.

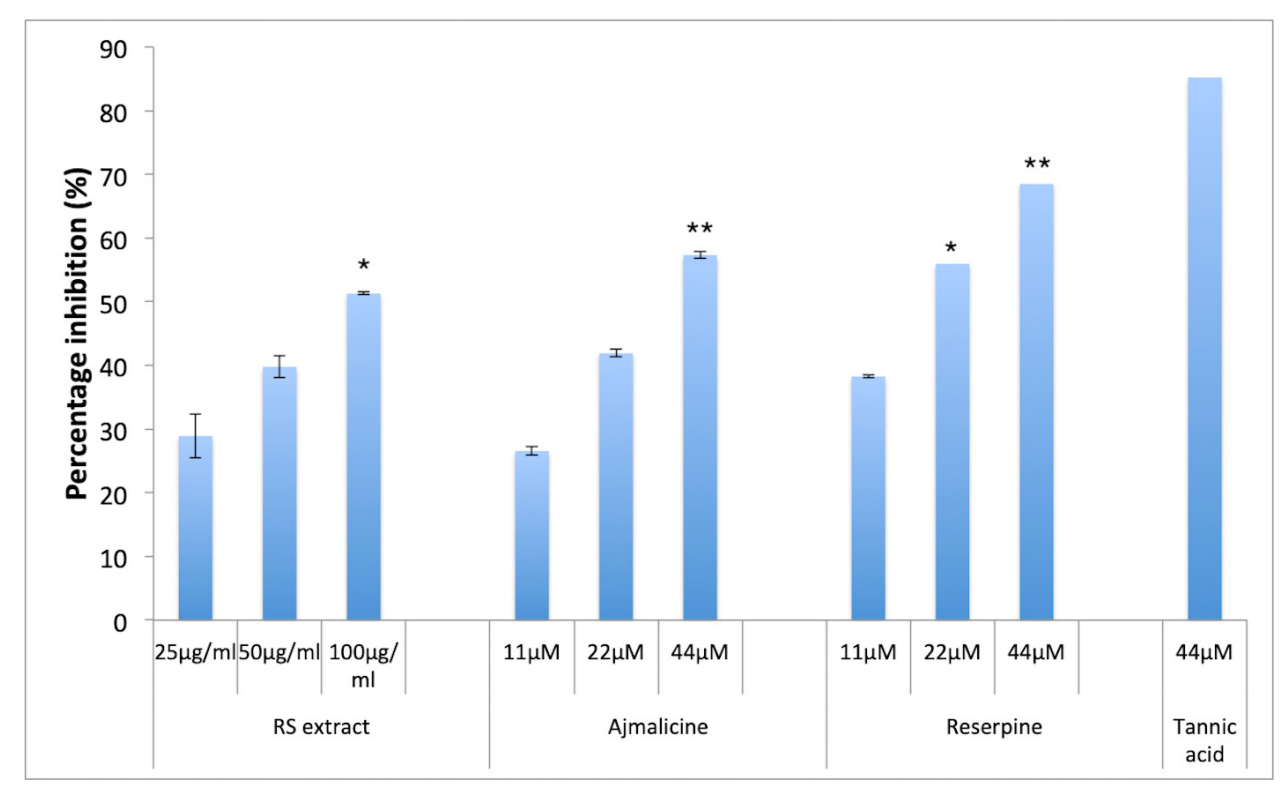

Figure 5. Percentage inhibition of $\mathrm{A} \beta 42$ aggregates formation; RS—R.serpentina extract (100, 50, $25 \mu \mathrm{g} / \mathrm{mL})$; AJM-Ajmalicine (44, 22, $11 \mu \mathrm{M})$; RES-Reserpine (44, 22, $11 \mu \mathrm{M})$; NC-PC12 cells treated with A $\beta 42$ only $(40 \mu \mathrm{M})$; PC-tannic acid $(44 \mu \mathrm{M})$, data represented as mean $\pm \mathrm{SEM}, n=3$; and difference in mean is statistically significant $\left({ }^{*}\right) p<0.05$ and very significant $\left({ }^{* *}\right) p<0.01$ as compared to control groups.

ThT fluorescence emission spectrum (400-650 nm) showed concentration dependent percentage inhibition of aggregation by test compounds (Figure 6A,C,E) supplement the ThT results mentioned above. A $\beta 42$ fibrils showed fluorescence emission maxima at $480 \mathrm{~nm}$. The test compound $(10-40 \mu \mathrm{M})$ showed relative decrease in intensity of fluorescence emission spectra as compared to $A \beta 42$ fibrils alone. 
A.

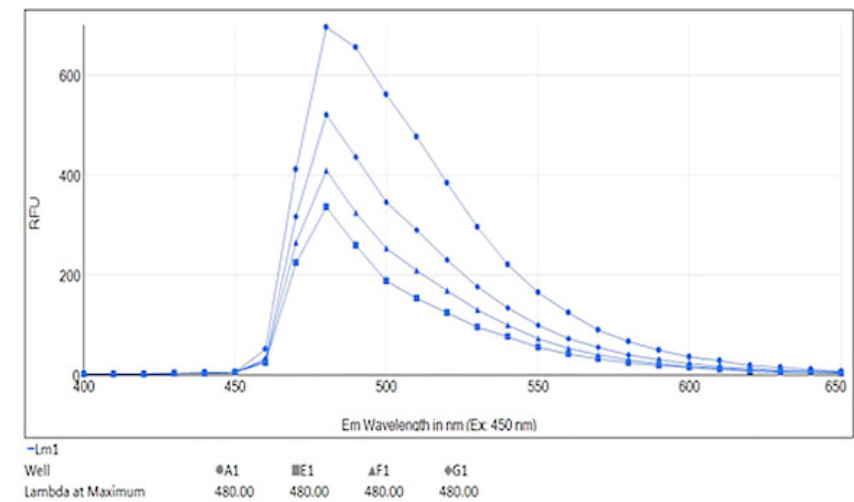

A.

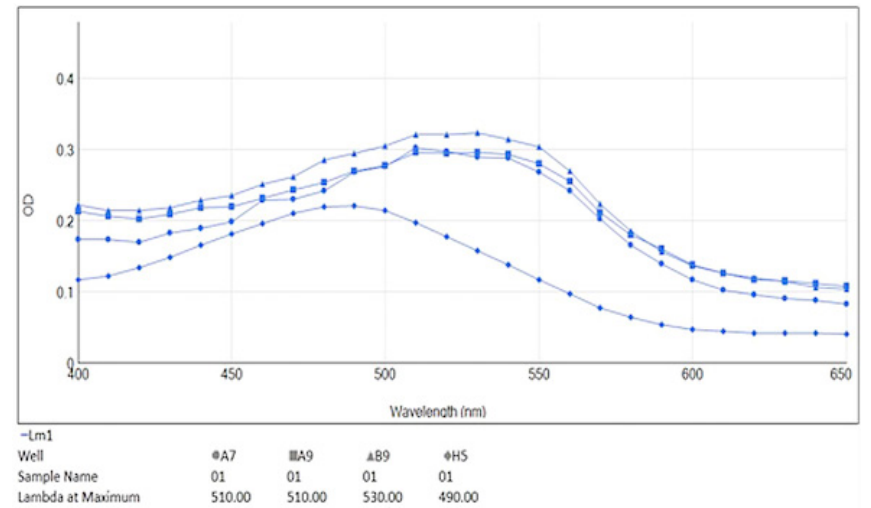

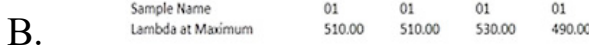

C.
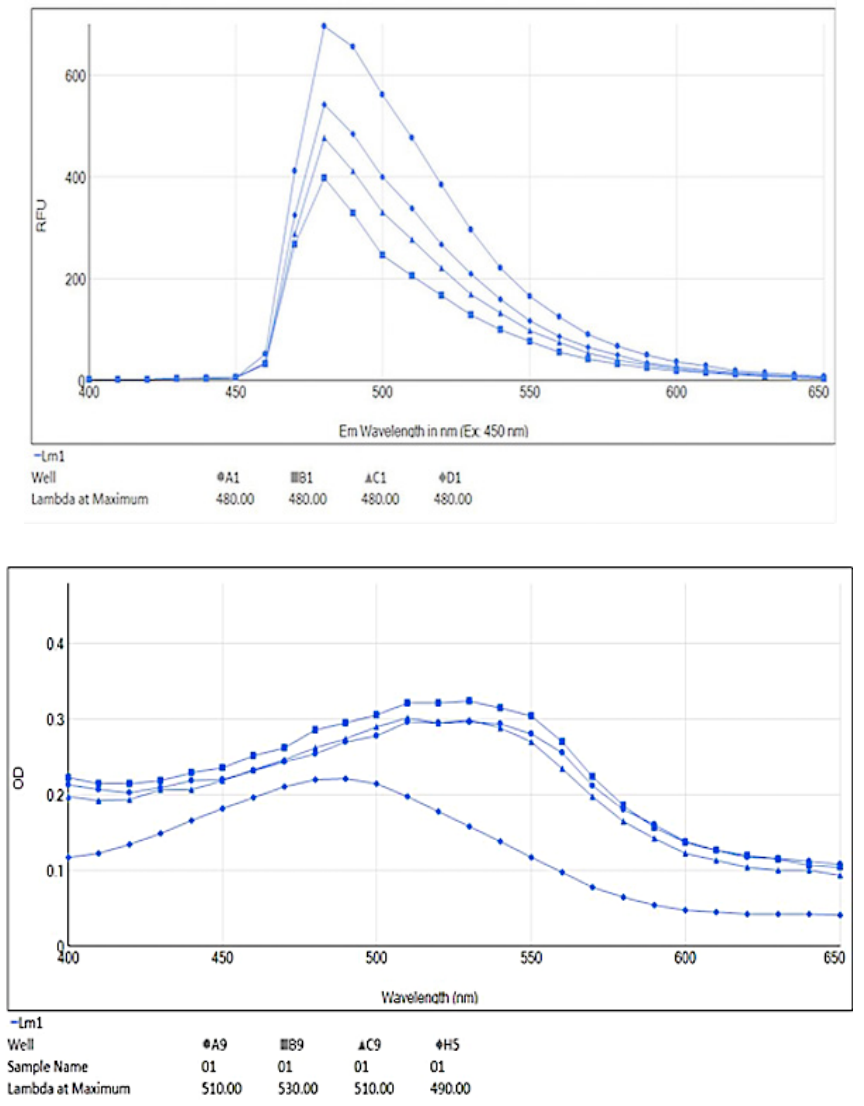

Figure 6. Cont. 
E.
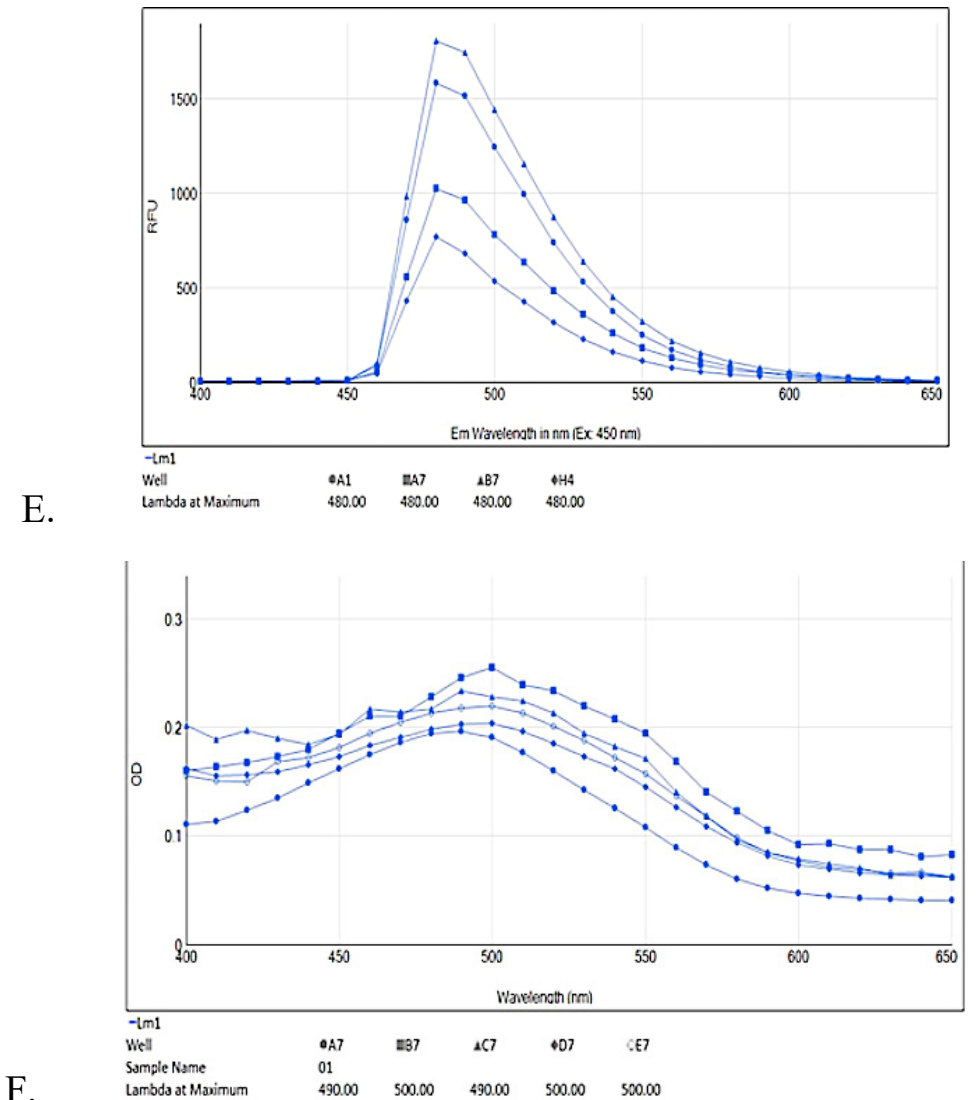

Figure 6. ThT fluorescence emission spectra $(\mathbf{A}, \mathbf{C}, \mathbf{E})$ alongside red shift of Congo red dye $(\mathbf{B}, \mathbf{D}, \mathbf{F})$ upon $\mathrm{A} \beta 42$ fibril formation with different test compound concentrations; RES (6A) ThT: A1-A $\beta 42$ only, G1-A $\beta 42+$ RES $11 \mu \mathrm{M}, \mathrm{F} 1-\mathrm{A} \beta 42+\mathrm{RES} 22 \mu \mathrm{M}, \mathrm{E} 1-\mathrm{A} \beta 42+\mathrm{RES} 44 \mu \mathrm{M}$; (6B) Congo red (CR): H5-CR only (490 nm), B9-A $\beta 42$ only (530 nm), A9-A $\beta 42+$ RES $22 \mu \mathrm{M}(510 \mathrm{~nm}), \mathrm{A} 7-\mathrm{A} \beta 42+\mathrm{RES}$ $44 \mu \mathrm{M}(510 \mathrm{~nm})$. AJM (6C) ThT: A1-A 342 only, D1-A $342+\mathrm{AJM} 11 \mu \mathrm{M}, \mathrm{C} 1-\mathrm{A} \beta 42+\mathrm{AJM} 22 \mu \mathrm{M}$, B1-A $342+$ AJM $44 \mu \mathrm{M}$; (6D) CR: H5-CR only (490 nm) B9-A 342 only (530 nm), A9-A $\beta 42+$ AJM $22 \mu \mathrm{M}(510 \mathrm{~nm}), \mathrm{C} 9-\mathrm{A} \beta 42+\mathrm{AJM} 44 \mu \mathrm{M}(510 \mathrm{~nm})$. R. serpentina extract spectra (6E) ThT: B7-A $\beta 42$

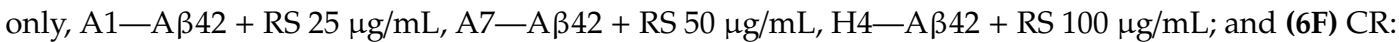
A7-CR only (490 nm), B7-A 342 only (500 nm), C7-A $342+$ RS $25 \mu \mathrm{g} / \mathrm{mL}(490 \mathrm{~nm}), \mathrm{E} 7-\mathrm{A} \beta 42+\mathrm{RS}$ $50 \mu \mathrm{g} / \mathrm{mL}(500 \mathrm{~nm}), \mathrm{D} 7-\mathrm{A} \beta 42+\mathrm{RS} 100 \mu \mathrm{g} / \mathrm{mL}$ (500 nm).

Congo red dye absorption spectra also support ThT determination of A $\beta 42$ fibril inhibition in spectral shift assay. Upon A $\beta 42$ interaction, $C R$ undergoes a red shift in absorbance from $480 \mathrm{~nm}$ to $500-550 \mathrm{~nm}$. CR assay showed a typical absorbance at $490 \mathrm{~nm}$ whereas when $A \beta 42$ added to $C R$ the absorbance wavelength is shifted to $530 \mathrm{~nm}$ (Figure 6B,D,F). RES, AJM, and R. serpentina extract incubated with $A \beta 42$ fibrils demonstrated reduced $C R$ red shift close to $510 \mathrm{~nm}$ indicating strong anti-aggregation property of test compounds.

\subsection{Evaluation of Inhibition of $\beta$ Sheet Formation}

A $\beta 42$ undergoes conformational changes during the process of oligomerization from random coil $\alpha$-helix to structured $\beta$-sheets [14]. This change in the secondary structure is measured by circular dichroism (CD) spectroscopy in far UV region (200-250 nm), where the increase in negative bend near $215 \mathrm{~nm}$ is directly proportional to increased $\beta$-sheets content. CD spectra of $A \beta 42$ co-incubated with RES and AJM showed that the process of $A \beta 42$ oligomerization is strongly inhibited in the presence of the test compounds (Figure 7) as compared to control (A $\beta 42$ only). 


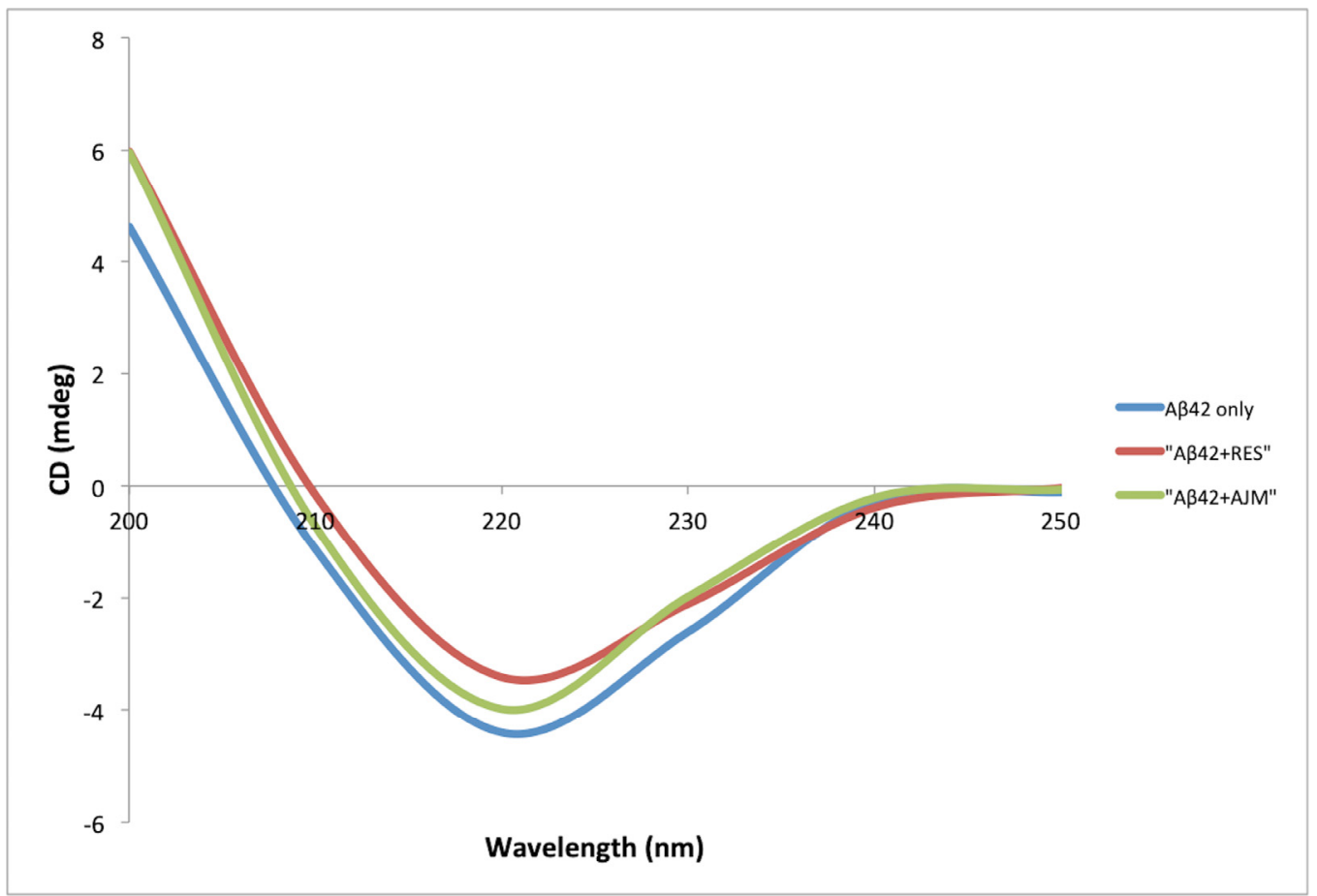

Figure 7. Circular dichroism (CD) spectra of $A \beta 42(22 \mu \mathrm{M})$ alone (blue), $\mathrm{A} \beta 42$ with RES (22 $\mu \mathrm{M})(\mathrm{red})$, and $\mathrm{A} \beta 42$ with AJM $(22 \mu \mathrm{M})$ (green).

The secondary structure content ( $\alpha$-helix, $\beta$-sheets, and turns) was determined using CD spectra analysis software [14]. During A $\beta$ fibrillation process, $\alpha$-helix structure was found to be zero after $48 \mathrm{~h}$ incubation, while the $\beta$-sheet content increased to $75 \%$ in A $\beta 42$ control (Table 3 ). RES demonstrated $64 \%$ inhibition in $\beta$-sheet formation whereas AJM inhibited the aggregation process to $53 \%$ as compared to control (A $\beta 42$ only). This result is complementary to inhibition percentage of $A \beta 42$ aggregation shown by ThT analysis.

Table 3. Estimated secondary structure content (\%) using BeStSel (Beta structure selection) software from CD spectra.

\begin{tabular}{cccc}
\hline Secondary Structure & $\mathbf{A} \boldsymbol{\beta}$ 42 Control (\%) & A $\beta \mathbf{4 2}+$ RES (\%) & A $\beta$ 42 + AJM (\%) \\
\hline$\alpha$-helix & 0.0 & 0.0 & 0.0 \\
$\beta$-sheet (antiparallel) & 74.9 & 27.3 & 35.2 \\
$\beta$-sheet (parallel) & 16.5 & 0.0 & 0.0 \\
Turn & 8.6 & 17.8 & 11.7 \\
Others & 0.0 & 54.9 & 53.1 \\
\hline
\end{tabular}

\subsection{Morphological Validation of Inhibition of A $\beta 42$ Aggregates Formation}

The influence of RES and AJM on fibril formation was studied by analyzing the morphologies of A $\beta 42$ aggregates by TEM. After 48 h of aggregation process, A $\beta 42$ control showed abundant long, branched, and dense fibrils with peptide nucleation, which is characteristic of amyloids whereas RES and AJM shows shorter, loose, and less A $\beta 42$ fibrils along with small oligomers (Figure 8). 


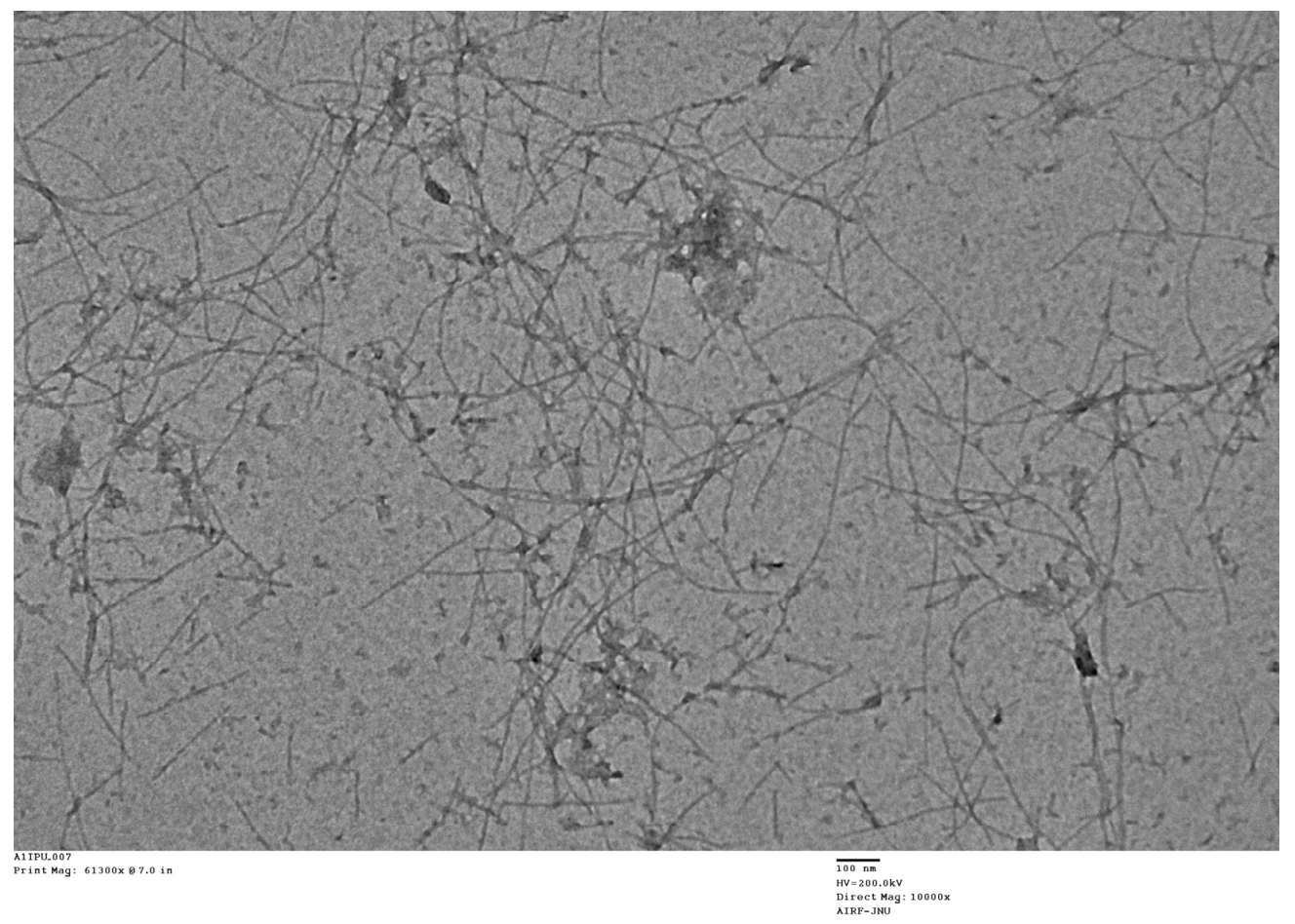

A.

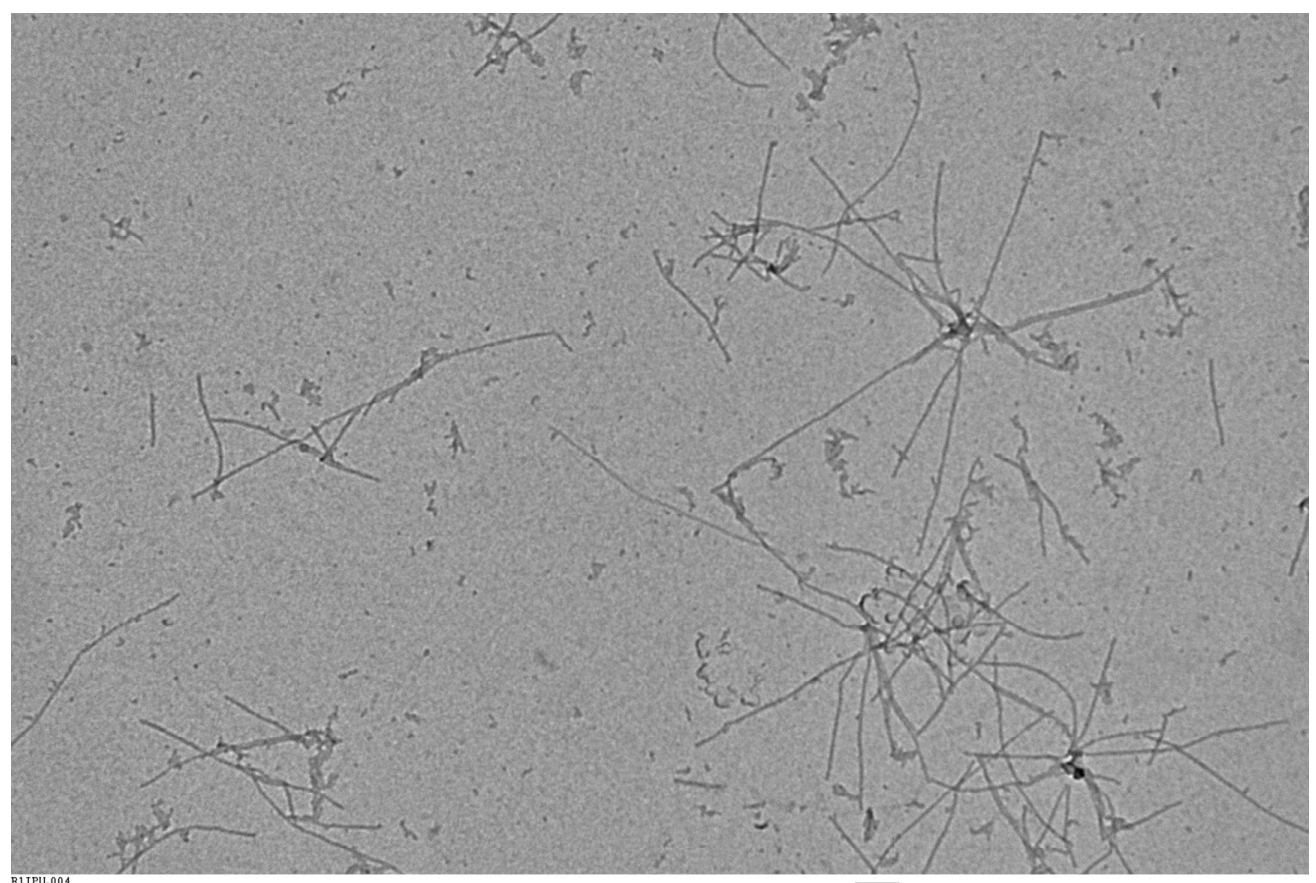

B.

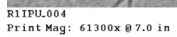

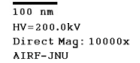

Figure 8. Cont. 
C.

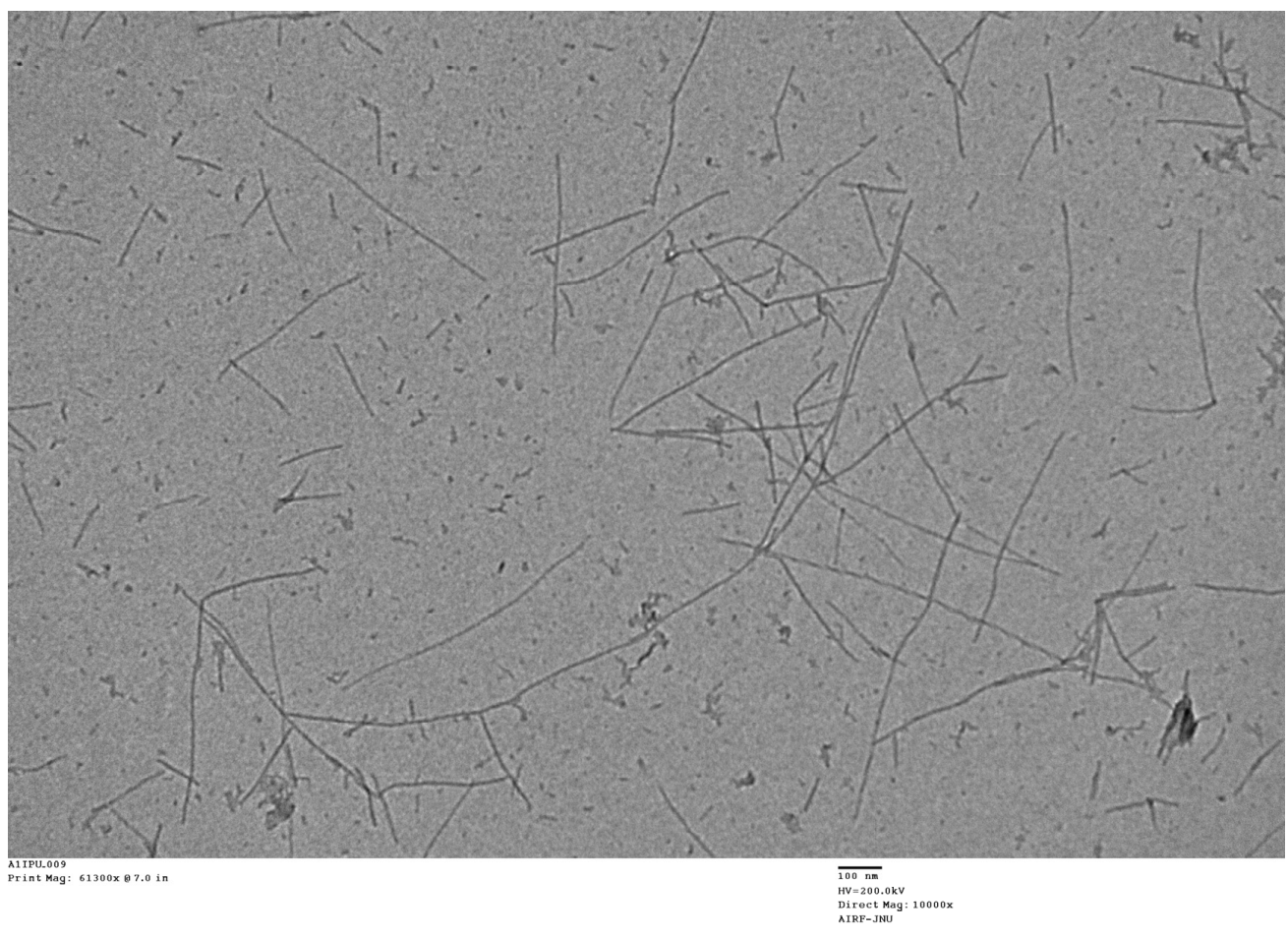

Figure 8. Transmission electron microscopy images of (A) - A $\beta 42$ control incubated at $37^{\circ} \mathrm{C}$ for $48 \mathrm{~h}$; (B) - A $\beta 42+44 \mu \mathrm{M}$ RES incubated at $37^{\circ} \mathrm{C}$ for $48 \mathrm{~h}$; and (C) - A $\beta 42+44 \mu \mathrm{M}$ AJM incubated at $37^{\circ} \mathrm{C}$ for $48 \mathrm{~h}$. Images were presented at $100 \mathrm{~nm}$.

\subsection{RES and AJM Protects PC12 Cells Against A $\beta 42$ Inflicted Cytotoxicity}

Further investigation was done to study the cytotoxic effect of $A \beta 42$ and protection against its neurotoxic effect by RES and AJM towards PC12 cells using MTT assay. PC12 cells resemble the phenotype of sympathetic ganglion neurons and are therefore used as model system to study neuroprotection against damages in $\mathrm{AD}$ [15]. $\mathrm{A} \beta 42$ is more toxic than $\mathrm{A} \beta 40$ oligomers in $\mathrm{AD}$, therefore in the current study $\mathrm{A} \beta 42$ was used to induce toxicity. PC12 cells exposed to various concentrations of $\mathrm{A} \beta 42(2.5-80 \mu \mathrm{M})$ for $24 \mathrm{~h}$ showed concentration dependent cytotoxicity, evident by decrease in the rate of MTT reduction. Therefore, to study the protection by compounds, a fixed concentration of A $\beta 4240 \mu \mathrm{M}$ was used to induce damage towards PC12 cells.

PC12 cells showed significant concentration dependent survival in the presence of RES (92\%) and AJM $(67 \%)$ at equimolar concentration of A $\beta 42(40 \mu \mathrm{M})$. R. serpentina extract also imparted $55 \%$ protection against $\mathrm{A} \beta 42$ cytotoxicity at $100 \mu \mathrm{g} / \mathrm{mL}$ which was comparable to the protection given by homotaurine (58\%), used as positive control in the study (Figure 9). 


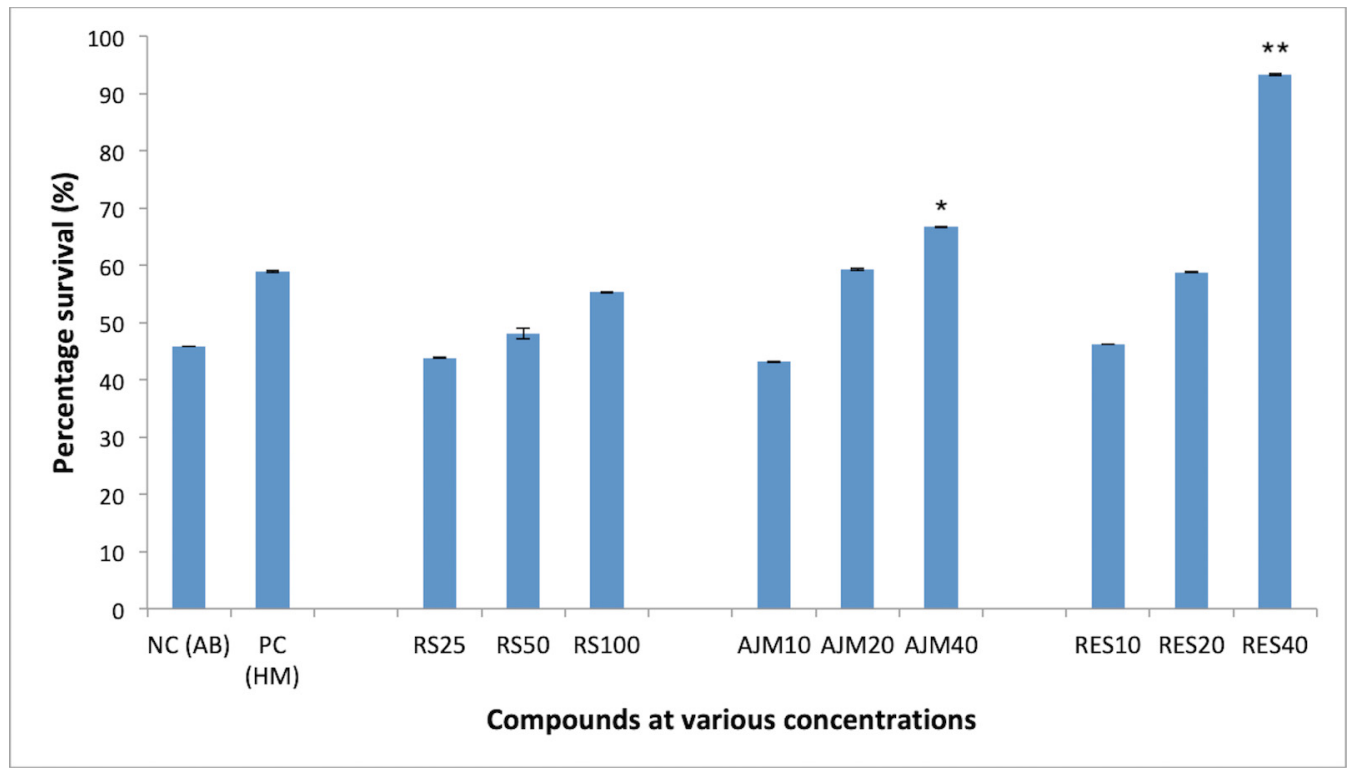

Figure 9. Concentration dependent percentage survival by MTT assay of A $\beta 42$ fibrils (48 hrs) induced neurotoxicity on PC12 cells; RS-R.serpentina extract (100, 50, $25 \mu \mathrm{g} / \mathrm{mL})$; AJM-Ajmalicine (40, 20, $10 \mu \mathrm{M})$; RES-Reserpine (40, 20, $10 \mu \mathrm{M})$; NC-PC12 cells treated with A $\beta 42$ only $(40 \mu \mathrm{M})$; PC-Homotaurine $(40 \mu \mathrm{M})$, data represented as mean $\pm \mathrm{SEM}, n=3$; and difference in mean is statistically significant $\left.{ }^{*}\right) p<0.05$ and very significant $\left.{ }^{* *}\right) p<0.01$ as compared to control group.

\subsection{In Vitro Neuroprotection Against Oxidative Stress}

Oxidative stress and generation of ROS have been shown to induce lipid peroxidation in cell membrane, which leads to cellular damage and subsequent cell death. Thus, the protective effect of RES and AJM against $\mathrm{H}_{2} \mathrm{O}_{2}$ induced oxidative stress towards PC12 cells was evaluated by MTT assay. Figure 10 showed significant protection against $\mathrm{H}_{2} \mathrm{O}_{2}$ cytotoxicity was observed in PC12 cells after pre-incubation with $R$. serpentina extract and its indole alkaloids RES and AJM. At extract concentration of $100 \mu \mathrm{g} / \mathrm{mL}$ highest viability was observed $(86.4 \%)$ as compared to $31 \%$ viability in negative control group $\left(\mathrm{H}_{2} \mathrm{O}_{2}\right.$ treatment alone). While PC12 cells had statistically significant results, surviving to $93 \%$ with RES $(40 \mu \mathrm{M})$ treatment and to $89 \%$ with AJM $(40 \mu \mathrm{M})$ treatment. The positive control glutathione (GSH) used in the study imparted $91 \%$ protection against $\mathrm{H}_{2} \mathrm{O}_{2}$ induced oxidative stress. 


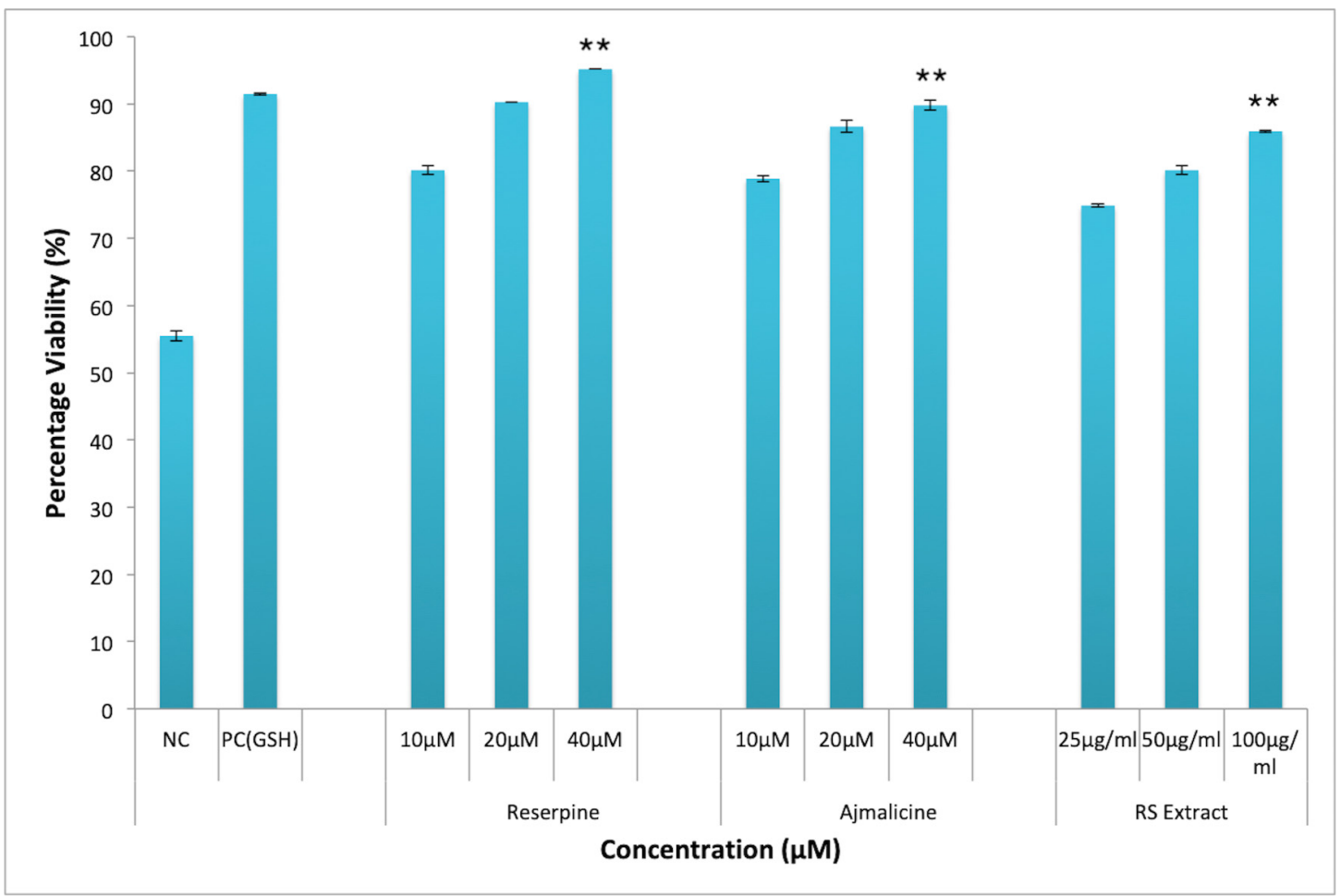

Figure 10. Neuroprotective effect against $\mathrm{H}_{2} \mathrm{O}_{2}$ induced cytotoxicity in PC12 cells; RES-Reserpine (40, 20, $10 \mu \mathrm{M})$; AJM-Ajmalicine (40, 20, $10 \mu \mathrm{M})$; RS-R.serpentina extract $(100,50,25 \mu \mathrm{g} / \mathrm{mL})$; PC: positive control (Glutathione, $40 \mu \mathrm{M})$; $\mathrm{NC}$-negative control $\left(\mathrm{H}_{2} \mathrm{O}_{2}\right.$ alone, $\left.200 \mu \mathrm{M}\right)$; values represents mean \pm SEM, $n=3$; and difference in mean is statistically significant $\left.{ }^{* *}\right) p<0.05$ as compared to control group.

\subsection{Evaluation of Dual Anti-Cholinesterase Potential of RES and AJM}

Cholinergic neurotransmission is severely affected in $\mathrm{AD}$, thus, to prolong neurotransmission a suitable drug compound must have anti-cholinesterase effect. RES and AJM achieved statistically significant dual anticholinesterase inhibition along with $R$. serpentina extract in concentration dependent manner (Figure 11). R. serpentina extract demonstrated 85\% AChE inhibition at $200 \mu \mathrm{g} / \mathrm{mL}$, post which a plateau response indicated enzyme saturation at $400 \mu \mathrm{g} / \mathrm{mL}$ ( $89 \%$ inhibition). RES at $50 \mu \mathrm{M}$ concentration gave highest relative inhibition (96\%), which is slightly higher than positive control donepezil inhibition percentage of AChE (94\%). AJM showed $90 \%$ inhibition at $50 \mu \mathrm{M}$ concentration. R. serpentina extract showed $\mathrm{IC}_{50}$ value of $14 \mu \mathrm{g} / \mathrm{mL}$ and $22 \mu \mathrm{g} / \mathrm{mL}$ for AChE and BuChE, respectively. 
A.

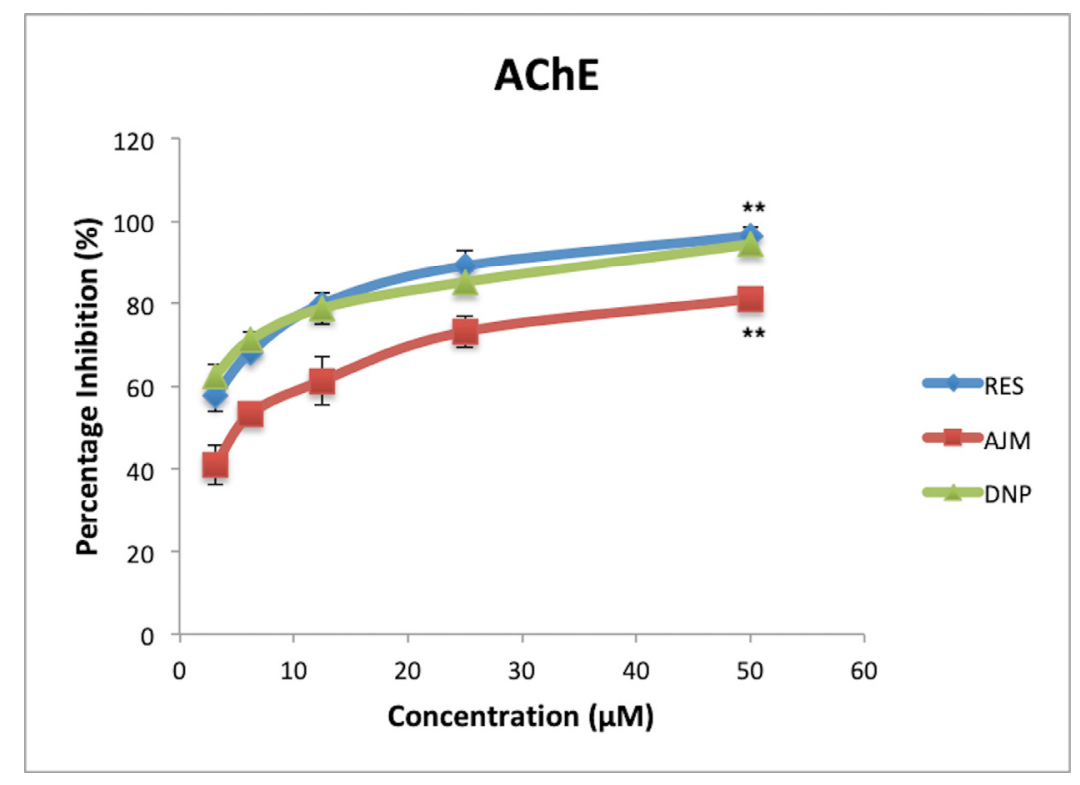

B.

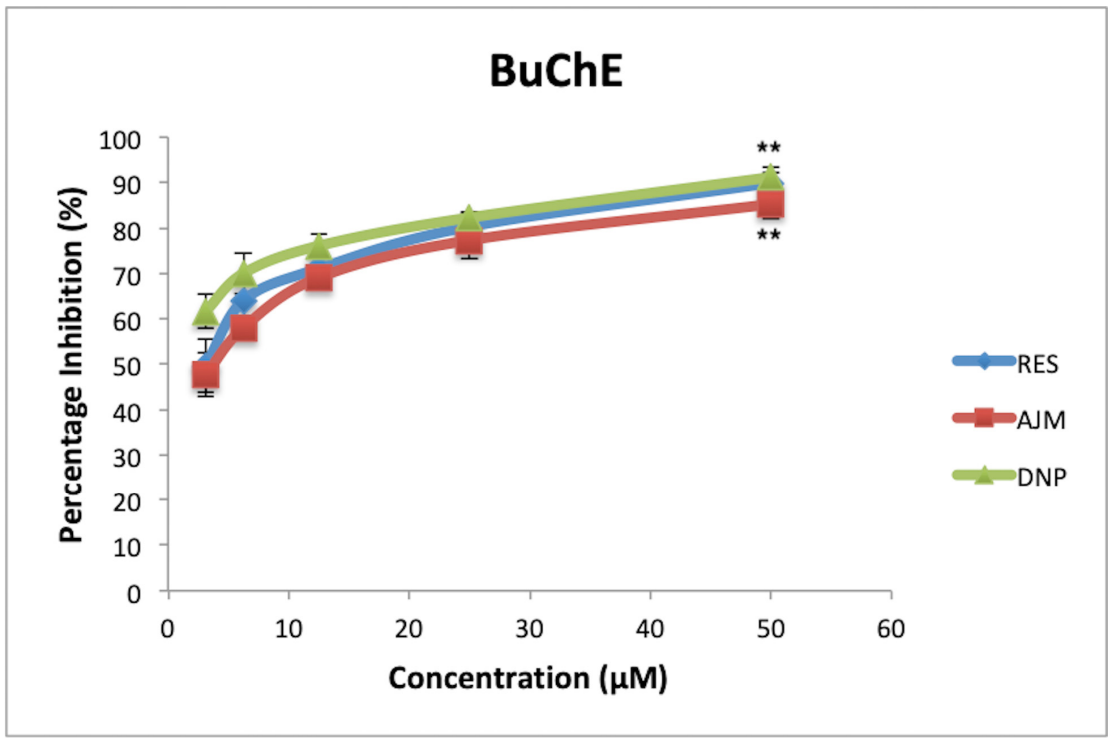

Figure 11. (A) acetylcholiesterase (AChE) percentage inhibition; (B) butyrylcholinesterase (BuChE) percentage inhibition at various tested concentrations of compounds (3.125-50 $\mu \mathrm{M})$; RES-reserpine, AJM-ajmalicine, DNP-donepezil; values represent mean $\pm \mathrm{SEM}, n=3$; and difference in mean is statistically very significant $\left.{ }^{* *}\right) p<0.001$ as compared to control groups.

Table 4 indicates the $\mathrm{IC}_{50}$ values along with the selectivity of the inhibition by respective compounds for $\mathrm{AChE}$ and BuChE. Selectivity is the measure of inhibition for a particular enzyme over the other. In later stages of $\mathrm{AD}, \mathrm{BuChE}$ levels increases in brain. BuChE catalyzes acetylcholine as it's substrate. Therefore, the BuChE inhibition becomes important along with AChE inhibition. Although RES and AJM have selectivity for AChE, the results suggest almost equivalent inhibition for BuChE. 
Table 4. Inhibitory activity ( $\left.\mathrm{IC}_{50}\right)$ and selectivity index (SI) of the compounds investigated against $\mathrm{AChE}$ and BuChE.

\begin{tabular}{|c|c|c|c|}
\hline \multirow{2}{*}{ Compound } & \multicolumn{2}{|c|}{$\mathrm{IC}_{50}(\mu \mathrm{M} \pm \mathrm{SD}) / \mathrm{IC} C_{50}(\mu \mathrm{g} / \mathrm{mL} \pm \mathrm{SD})$} & \multirow{2}{*}{ SI } \\
\hline & AChE IC 50 & BuChE IC $_{50}$ & \\
\hline Reserpine & $1.7 \pm 2.08 \mu \mathrm{M}$ & $2.8 \pm 1.84 \mu \mathrm{M}$ & 1.65 \\
\hline Ajmalicine & $3.5 \pm 1.41 \mu \mathrm{M}$ & $5.44 \pm 1.75 \mu \mathrm{M}$ & 1.55 \\
\hline R. serpentina extract & $14 \pm 3.62 \mu \mathrm{g} / \mathrm{ml}$ & $22 \pm 3.10 \mu \mathrm{g} / \mathrm{ml}$ & 1.57 \\
\hline Donepzil & $0.98 \pm 1.20 \mu \mathrm{M}$ & $1 \pm 2.89 \mu \mathrm{M}$ & 1.02 \\
\hline
\end{tabular}

Regression analyses was used to determine $\mathrm{IC}_{50}$ values were and expressed as the means $\pm \mathrm{SD}$ of three replicate determinations. Selectivity index here is the $\mathrm{AChE}$ selectivity over BuChE defined as $\mathrm{IC}_{50} \mathrm{BuChE} / \mathrm{IC}_{50} \mathrm{AChE}$ affinity ratio.

\section{9. $\beta$-Site Amyloid Precursor Protein Cleaving Enzyme 1 Inhibition}

The BACE-1 enzyme inhibition has been shown to reduce the amount of pathogenic $A \beta 42$ formation, which makes it one of the important targets for AD [16]. The results of the current study demonstrate the efficacy of lead compounds to inhibit the enzyme effectively (Figure 12). AJM showed the maximum inhibition of BACE- 1 activity to $69 \%$ at $50 \mu \mathrm{M}$ concentration whereas RES imparted $47 \%$ inhibition at same concentration. Therefore, AJM inhibitory potential was evaluated at various concentrations and AJM showed statistically significant BACE-1 enzyme inhibition in concentration dependent manner at various concentrations tested $(25,50,100 \mu \mathrm{M})$ (Figure 12).

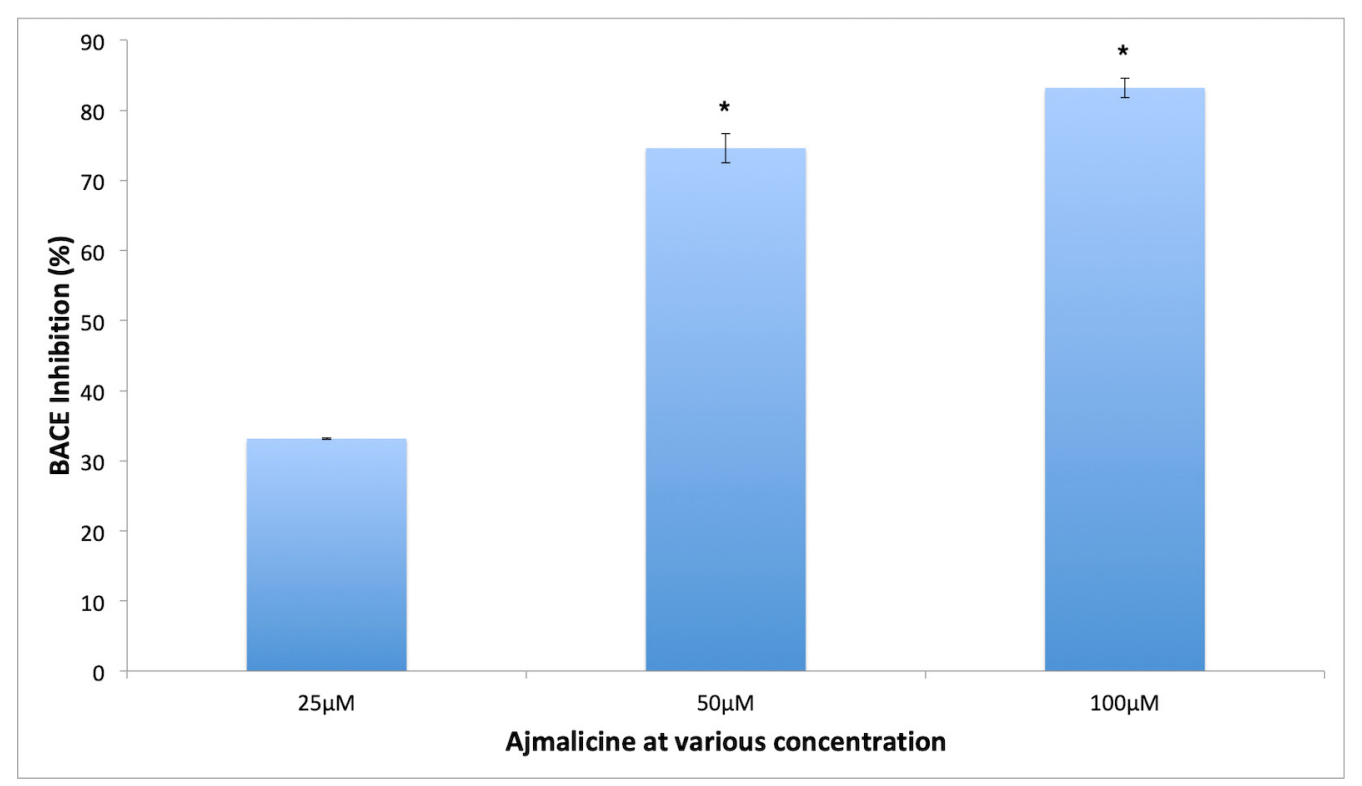

Figure 12. Concentration dependent $\beta$-site amyloid cleaving enzyme (BACE-1) inhibitory activity of AJM; values represent mean $\pm \mathrm{SEM}, n=3$; and * difference in mean is statistically very significant $p<0.001$ as compared to control group.

\subsection{Inhibition of Monoaminoxidase-B Enzyme}

MAO-B is responsible for production of toxic oxygenated free radicals, which is responsible for neurodegeneration in AD. RES and AJM significantly inhibited the MAO-B enzyme in a concentration dependent manner, at $10 \mu \mathrm{M}$, both the tested compounds gave comparable inhibition for MAO-B enzyme, $89 \%(40 \mu \mathrm{M})$ inhibition (Figure 13) was shown at higher concentrations compared to control. 


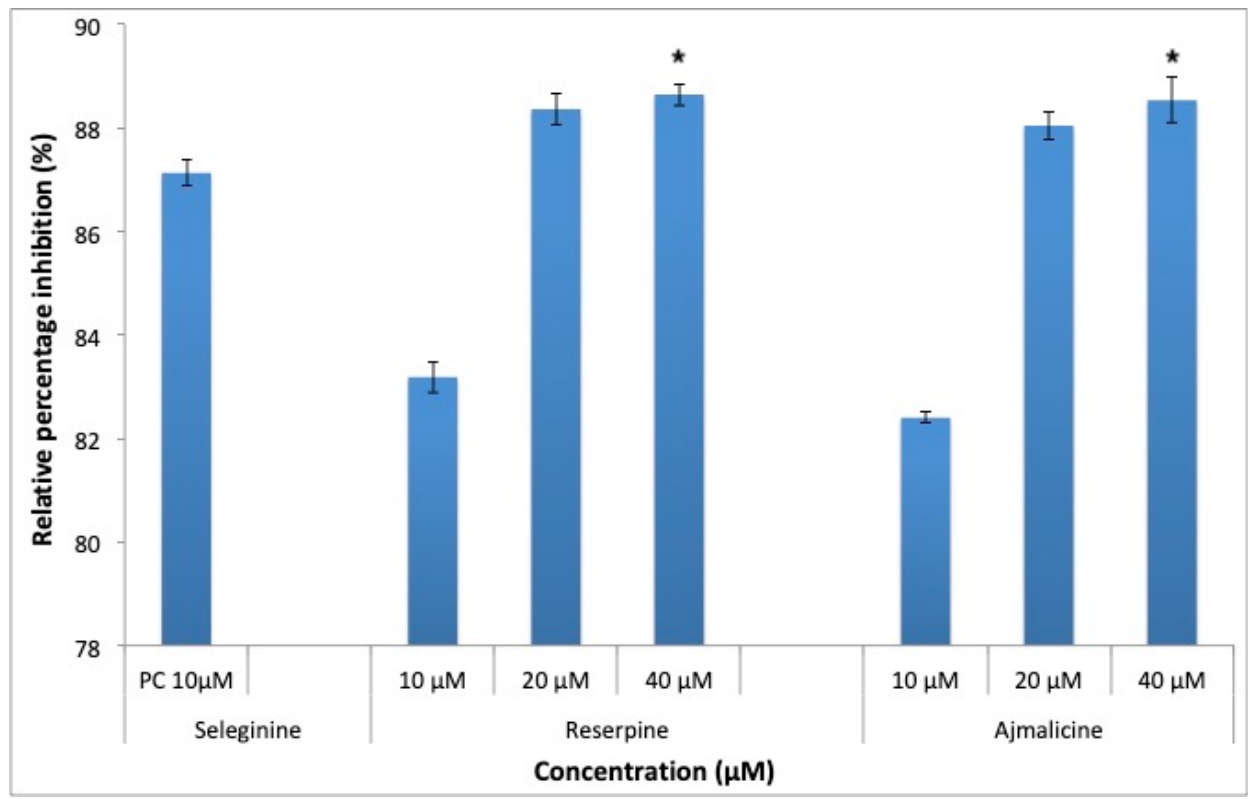

Figure 13. Monoamine oxidase-B (MAO-B) inhibition by positive control (selegiline) at $10 \mu \mathrm{M}$, RES and $\mathrm{AJM}$ at 10, 20 and $40 \mu \mathrm{M}$ concentration; values represents mean $\pm \mathrm{SEM}, n=3$; and * difference in mean is statistically very significant $p<0.001$ as compared to control group.

\subsection{Molecular Interaction of RES and AJM with AD Targets}

Molecular docking revealed interaction of RES and AJM with catalytic site residues of studied AD targets (A $\beta 42, \mathrm{AChE}, \mathrm{BuChE}, \mathrm{BACE}-1$, and MAO-B) giving insight of the mechanism of inhibition of respective enzymes and peptide that correlate with in vitro studies. Molecular docking analysis (Table 5) clearly indicates that RES and AJM are excellent multi-target directed ligands capable of inhibiting $\mathrm{A} \beta 42$ aggregation and key enzymes implicated in AD such as AChE, BuChE, BACE-1, and MAO-B. RES and AJM strongly interacted with A $\beta 42$ key residues with very low binding energy. Lower binding energy implies stable protein-ligand complex, thus, strong interaction. Based on the binding energies RES and AJM demonstrated better A $\beta 42$ anti-aggregation potential as compared to positive control (tannic acid). Similarly, RES and AJM are better AChE and BuChE inhibitors as compared to positive control (galanthamine and tacrine) attributed to low binding energies signifying strong and stable interaction. AJM interacted with MAO-B catalytic site residue through hydrogen bond while RES interacted with comparatively weak hydrophobic environment suggesting AJM is better MAO-B inhibitor than RES.

Table 5. Molecular interactions as observed in ligand docked complexes of target receptor proteins obtained from Autodock 4.2.

\begin{tabular}{|c|c|c|c|c|c|c|}
\hline S.No. & Ligand & AD Target & $\begin{array}{l}\text { Binding } \\
\text { Energy } \\
\text { (Kcal/mol) }\end{array}$ & $\begin{array}{c}\text { No. of } \\
\text { H-bonds }\end{array}$ & Interacting Residues & Bond Angle (Å) \\
\hline \multirow{5}{*}{1.} & \multirow{5}{*}{$\begin{array}{c}\text { RES } \\
\text { (Reserpine) }\end{array}$} & $\mathrm{A} \beta 42$ & -9.45 & 5 & $\begin{array}{l}\text { Asp23, Gly33, Lys28, } \\
\text { Leu34, Val36 }\end{array}$ & $\begin{array}{c}\text { 3.2, 2.4, 2.4, 3.3, } \\
\text { 3.3, hydrophobic } \\
\text { with Lys28 }\end{array}$ \\
\hline & & AChE & -11.42 & 7 & $\begin{array}{l}\text { Phe295, Arg296, } \\
\text { Tyr337, Ser125, } \\
\text { Glu334, Tyr72 }\end{array}$ & $\begin{array}{c}2.3,3.5,1.9 \\
(2.6,2.3), 2.4,2.7\end{array}$ \\
\hline & & $\mathrm{BuChE}$ & -7.68 & 4 & $\begin{array}{l}\text { Asn68, Thr120, } \\
\text { Ala277, Val288 }\end{array}$ & $3.4,2.3,3.4,2.4$ \\
\hline & & BACE-1 & -8.8 & 5 & Thr72, Asp32, Asp217, & $\begin{array}{c}2.6,(3.2,3.3), \\
(3.5,3.0)\end{array}$ \\
\hline & & MAO-B & -3.7 & 3 & Val85, Tyr326, Ile199 & $3.4,2.4,2.8$ \\
\hline
\end{tabular}


Table 5. Cont

\begin{tabular}{|c|c|c|c|c|c|c|}
\hline S.No. & Ligand & AD Target & $\begin{array}{c}\text { Binding } \\
\text { Energy } \\
\text { (Kcal/mol) }\end{array}$ & $\begin{array}{l}\text { No. of } \\
\text { H-bonds }\end{array}$ & Interacting Residues & Bond Angle ( \\
\hline \multirow{5}{*}{2.} & \multirow{5}{*}{$\begin{array}{c}\text { AJM } \\
\text { (Ajmalicine) }\end{array}$} & $\mathrm{A} \beta 42$ & -8.4 & 1 & Asp 23 & 3.2 \\
\hline & & AChE & -9.7 & 3 & $\begin{array}{l}\text { Phe295, Tyr286, } \\
\text { Phe297 }\end{array}$ & $2.1,3.0,3.2$ \\
\hline & & $\mathrm{BuChE}$ & -6.6 & 4 & $\begin{array}{l}\text { Asn68, Asp70, } \\
\text { Trp82, Thr120 }\end{array}$ & $3.6,2.1,2.5,2.1$ \\
\hline & & BACE-1 & -8.9 & $\begin{array}{c}0 \\
\text { (all hydro-phobic) }\end{array}$ & Asp32, Asp228 & \\
\hline & & MAO-B & -5.6 & 6 & $\begin{array}{l}\text { Glu85, Pro102, } \\
\text { Thr202, Glu84 }\end{array}$ & $\begin{array}{c}3.3,2.4,2.1 \\
(3.2,3.3)\end{array}$ \\
\hline \multicolumn{7}{|c|}{ Positive Control } \\
\hline 3. & Tannic acid & $\mathrm{A} \beta 42$ & -6.5 & 2 & Asp23, Lys28 & $2.1,1.9$ \\
\hline 4. & Galanthamine & AChE & -10.8 & 3 & $\begin{array}{l}\text { Tyr337, Glu202, } \\
\text { Ser203 }\end{array}$ & $1.8,2.2,1.7$ \\
\hline 5. & Tacrine & BuChE & -6.52 & 1 & Trp82 & 2.3 \\
\hline 6. & BXD & BACE-1 & -10.4 & 4 & $\begin{array}{l}\text { ASP32, GLY34, } \\
\text { PHE108, ASP217 }\end{array}$ & $1.9,2.2,2.5,2.1$ \\
\hline 7. & Rasagilline & MAO-B & -7.5 & $\begin{array}{c}0 \\
\text { (all hydro-phobic) }\end{array}$ & $\begin{array}{l}\text { Gln206, Phe343, } \\
\text { Tyr326, Leu171 }\end{array}$ & \\
\hline
\end{tabular}

\subsection{Pharmacokinetics Analysis}

Pharmacokinetics analysis for ADMET, of identified phytoconstituents showed that AJM proves to be a more ideal drug molecule as it obeys Lipinski rule of five along with suitable profile to cross the blood brain barrier (BBB) (Table 6). While RES failed to obey Lipinski rule of five majorly because of its molecular weight (above $500 \mathrm{~g} / \mathrm{mol}$ ) but showed good potential to cross the BBB. All the positive controls showed ideal drug profiles.

Table 6. Pharmacokinetics ADMET prediction by Drulito against Lipinski rule of five and blood-brain-barrier filter.

\begin{tabular}{cccccccccc}
\hline Compound & $\begin{array}{c}\text { MW } \\
(\mathbf{g} / \mathbf{m o l})\end{array}$ & $\mathbf{l o g} \mathbf{P}$ & AlogP & HBA & HBD & TPSA & nHB & $\begin{array}{c}\text { nAcidic } \\
\text { group }\end{array}$ & $\begin{array}{c}\text { Filter } \\
\text { L/B }\end{array}$ \\
\hline Reserpine & 608.27 & 2.672 & -0.857 & 11 & 1 & 114.02 & 12 & 0 & $\mathrm{~B}$ \\
Ajmalicine & 352.18 & 1.906 & -0.068 & 5 & 1 & 50.8 & 6 & 0 & $\mathrm{~L} / \mathrm{B}$ \\
Tacrine & 198.12 & 1.121 & -0.748 & 2 & 1 & 38.38 & 3 & 0 & $\mathrm{~L} / \mathrm{B}$ \\
Galanthamine & 287.15 & 1.197 & -0.444 & 4 & 1 & 41.93 & 5 & 0 & $\mathrm{~L} / \mathrm{B}$ \\
Donepezil & 379.21 & 2.633 & 0.364 & 4 & 0 & 38.77 & 4 & 0 & $\mathrm{~L} / \mathrm{B}$ \\
Rasagiline & 171.1 & 1.446 & 1.092 & 1 & 1 & 12.03 & 2 & 0 & $\mathrm{~L} / \mathrm{B}$ \\
Tannic acid & 1701.17 & 9.537 & -5.356 & 46 & 25 & 777.9 & 71 & 0 & \\
\hline
\end{tabular}

MW—-molecular weight; $\log \mathrm{P}$ - partition coefficient; $\mathrm{A} \log \mathrm{P}$ - octanol-water partition coefficient; HBA= hydrogen bond acceptor; HBD — hydrogen bond donor; TPSA — total polar surface area; nHB — number of hydrogen bond; nAcidic group — number of acidic group; Filter L—Lipinski rule of five; and B-blood brain barrier.

\section{Discussion}

Pathophysiology of AD is attributed to diverse, complex factors such as cognitive decline, memory loss, and extracellular plaque formation along with neurofibrillary tangles. From the inception of amyloid cascade hypothesis to its reappraisal, it is considered to be the primary cause of this form of senile dementia $[17,18]$. With the advent of research and new disease progression insights, now we can assign more targets with responsibility towards either pathophysiology or associated symptoms [5]. Despite major pharma-research focused on discovering novel disease-modifying molecules, the current 
treatment for AD targets its affiliated symptoms only [6]. In accordance with the aforesaid fact, we investigated the potential of natural compounds from $R$. serpentina (reserpine and ajmalicine) for their MTDL properties.

Naturally occurring alkaloids have long been used in therapeutic strategies against AD, such as galanthamine and huperzineA that are used in providing symptomatic relief to AD patients [19]. $R$. serpentina is abundant in many indole alkaloids such as reserpine, serpentine, rauwolfine, sarpagine, ajmaline, yohimbine, and ajmalicine [10]. In the current study the most abundant phytoconstituents identified in our test extract by UPLC-QTOF method were RES and AJM. Previous studies have shown similar identification of secondary metabolite profile of $R$. serpentina by UPLC-UV [10,20]. RES and AJM were quantified by a novel method developed and validated for RP-HPLC using an UV detector. This method is rapid and precise as they give reliable elution at early retention time using organic mobile phase as compared to previously reported methods [21,22]. The RP-HPLC method used in the current study has many advantages as compared to previously reported methods. These advantages are low LOD and LOQ as it offers sensitive detection and quantification of RES and AJM in trace amount.

$\mathrm{A} \beta 42$ is a $4 \mathrm{KDa}$ fragment of mature APP, which self-aggregate to form toxic $\mathrm{A} \beta 42$ oligomers and finally proto-fibrils that are considered as a main pathological factor implicated in AD [23]. Compounds, which could inhibit $A \beta 42$ aggregation or reverse this process of peptide nucleation would be of great therapeutic interest. Current study results showed concentration dependent, statistically significant anti-amyloidogenic potential of RES, AJM, and hydro-alcoholic root extract of $R$. serpentina. The exact mechanism of $A \beta 42$ oligomerization to insoluble plaque formation is not clear but the secondary structure conformation studies suggest that $\beta$-sheet content is increased in $A \beta 42$ oligomerization [24]. $\mathrm{CD}$ analysis results were in accordance to this observation as the reduced percentage of $\beta$-sheet content in RES and AJM treated samples of A $\beta 42$ showed equivalent inhibition percentage in $A \beta 42$ self-aggregation. The fact is further validated with electron micrographs showing short, unbranched fibrils and no peptide nucleation in RES and AJM treated samples of A $\beta 42$ as compared to control (A $\beta 42$ only). Insight of the inhibition mechanism could be understood by observing interactions at the molecular level. As evident from molecular docking analysis, RES, and AJM stacks themselves in between adjacent $\beta$-sheets and therefore inhibit further oligomerization. RES forms hydrogen bond with key residue (Asp23) and interacted hydrophobically to Lys 28 of A $\beta 42$, bound internally in the steric zipper composed of KLVFFA (residues 16-21). Besides, RES also oriented itself to cover the hydrophobic core residues (Leu17, Val18, Phe19, and Phe20) of A $\beta 42$, stabilizing the complex further. A $\beta 42$ assembly requires Asp23 of one monomer to form a hydrogen bond with Lys28 of another monomer therefore to conclude RES can potentially inhibit A $\beta 42$ aggregation. Furthermore, RES gave a binding score comparable to positive control compound (tannic acid). AJM interacts more with hydrophobic core inside steric zipper via hydrophobic interactions. It also bound to Asp23 with one hydrogen bond therefore it covers the residue (Asp23) required for oligomerization and hence inhibited $A \beta 42$ aggregation process. $A \beta 42$ oligomerization has been shown to accelerate upon AChE binding to $A \beta 42$ by hydrophobic environment near peripheral active site (PAS) of AChE [25]. The indole ring of RES formed hydrogen bond with catalytic anionic site (CAS) residues Glu334 along with another hydrogen bond with Tyr72 in PAS of AChE. Similarly, AJM interacted with hydrogen bond towards Tyr286 (PAS residue) and Phe295-Phe297 in acyl binding pocket of CAS of AChE. Therefore, RES and AJM successfully occupy both the CAS and PAS of AChE, thereby inhibiting the enzyme as well inhibit AChE induced A $\beta 42$ aggregation. The molecular docking results are well complemented with in vitro results of enzyme inhibition assay.

In advanced cases of $\mathrm{AD}, \mathrm{BuChE}$ secretion increases responsible for hydrolysis of AChE as it's substrate. This accelerates the cholinergic decline process further. RES and AJM counteract the decrease in neurotransmitter levels (AChE) by significantly inhibiting BuChE in concentration dependent manner evident from in vitro enzyme inhibition assay. The molecular interactions showed strong binding energies of RES and AJM with BuChE, suggesting stable protein-ligand complex. Tacrine 
(known inhibitor) had lower docking score then RES and AJM. RES forms strong hydrogen bond with BuChE CAS residue (Val288) and occupies the PAS by interacting with a residue (Asn68) which lies near PAS (Asp70). Whereas AJM binds directly to CAS and PAS residues (Trp82 and Asp70, respectively). Thus, RES and AJM could prove to be better anti-cholinesterase drug ligands for therapeutics towards AD.

BACE-1 enzyme structure is found to exist in three different conformations based on a flap like secondary structure, which covers the active site of the enzyme. The BACE-1 structure (PDB ID 4D8C) used in the current study is closed flap structure, which is the dominant form exists upon binding to its substrate. Molecular docking analysis showed that the indole ring of RES interacts with the main catalytic site residues of the BACE-1 enzyme. The indole ring of RES acts as a hydrogen bond donor for Asp32, forming double hydrogen bond with catalytic site residue of BACE-1 while the isoprene tail of RES forms hydrophobic interaction in the catalytic gorge of BACE-1. On the other hand, AJM binds more strongly to BACE-1 with all hydrophobic interactions as it gave a high binding score with BACE-1. Probable explanation could be the stability AJM provides to the hydrophobic catalytic gorge of BACE-1 due to its compact size and orientation then RES. These molecular interactions are complemented with in vitro results showing statistically significant inhibition of BACE-1 enzyme, where observed potency of AJM is more than RES.

MAO-B enzyme plays an important role in generation of free radicals thus imparting oxidative stress at cellular level. RES and AJM inhibited MAO-B enzyme in concentration dependent manner comparable to positive control (selegiline). The in vitro results are complimented by molecular docking analysis where RES was observed to interact with the key catalytic site residues of MAO-B while AJM occupies the catalytic site by interacting with other residues there. RES interacted with Tyr326 and Ile199 by hydrogen bonding. AJM gave high binding score then RES probably because AJM formed more strong hydrogen bonds with residues surrounding catalytic site covering the main residues involved in hydrolysis of the substrate. The ADMET profile of AJM showed promising results of being able to act as ideal drug molecule with BBB permeability while RES structure could be utilized to develop active MTDL drug candidate with small molecular size.

\section{Materials and Methods}

\subsection{Materials}

LC-MS grade water, methanol, acetonitrile, formic acid, Zorbex UPLC $C_{18}$ Silica Column, Agilent 6520 QTOF instrument, acetylcholinesterase from electric eel, butyrylcholinesterase from equine serum, amyloid beta protein (Link biotech), thioflavin T, Congo red dye, reserpine, and ajmalicine were purchased from Sigma Aldrich, India. MAO-B inhibition kit by Biovision. BACE-1 activity assay kit by Sigma Aldrich. RPMI 1640 medium, FBS, PBS, and other tissue culture grade chemicals were purchased from Himedia, India. PC12 (rat pheochromocytoma) cell line was obtained from NCCS, Pune, India. All other reagents used were of analytical grade. All preparations used in tissue culture experiments were filtered through $0.45 \mu \mathrm{m}$ Axiva $25 \mathrm{~mm}$ CA filter. Ethical approval was obtained from GGS Indrapratha University for all the cell culture work done in proper confined facilities.

\subsection{Preparation of Hydro-Alcoholic Extract}

The NISCAIR authenticated dried R. serpentina root sample (voucher specimen number RS1-USBT stored in School of Biotechnology, GGS Indraprastha University) was infused in 1:1 ratio of ethanol and freshly boiled distilled (de-ionized) water. The infusion was kept in shaker at $40{ }^{\circ} \mathrm{C}$ for $48 \mathrm{hrs}$ and filtered. The supernatant was freeze dried (lyophilized) in lyophilizer for $24 \mathrm{~h}$. The yield obtained was calculated and freeze-dried aliquots were sealed properly to avoid any moisture inside the vials and stored in deep freezer $\left(-20^{\circ} \mathrm{C}\right)$ till further use. 


\subsection{Liquid Chromatography-Mass Spectrometry}

R. serpentina hydro-alcoholic root extract was analyzed using various mobile phase combinations for best possible resolution of chromatographic peaks. The LCMS run condition was tested four times for a standardized protocol development to estimate secondary metabolites profile (Table 7).

Table 7. Optimized UHPLC-QTOF condition for identification of phytoconstituents present in $R$. serpentina extract.

\begin{tabular}{cc}
\hline Variables & Conditions \\
\hline System & Agilent 6520 QTOF LC/MS system \\
Software & Agilent MassHunter B.05.00 \\
Column & Zorbax UPLC C 18 (100 mm $\times 2.1 \mathrm{~mm}$, i.d. $1.7 \mu \mathrm{m})$ \\
Mobile phase & Water with $0.01 \%$ formic acid (A) and methanol (B) \\
Flow Rate & $0.4 \mathrm{~mL} / \mathrm{min}$ \\
Fragmentor voltage & $150 \mathrm{~V}$ \\
Electron spray ionization (ESI) mode & Positive \\
Mass-to-charge $(m / z)$ scanning ratio & $100-1000 \mathrm{~m} / \mathrm{z}$ \\
Injection volume & $3 \mu \mathrm{L}$ \\
Column Temperature & $25^{\circ} \mathrm{C}$ \\
& Linear gradient: $0-5 \mathrm{~min}, 10-20 \% \mathrm{~B}$ \\
Elution & $5-14 \mathrm{~min}, 20-30 \% \mathrm{~B}$ \\
& $14-18 \mathrm{~min}, 30-75 \% \mathrm{~B}$ \\
& $18-22 \mathrm{~min}, 75-100 \% \mathrm{~B}$
\end{tabular}

\footnotetext{
Data analysis: The LCMS data was analyzed by Mass Hunter software developed by Agilent. Peaks generated in positive mode of ionization above $\geq 2000$ counts were considered with peak spacing tolerance of $0.0025 \mathrm{~m} / \mathrm{z}$ for better resolution of LC/MS. Mass Bank Workstation software along with METLIN database was used to estimate metabolite profile [26].
}

\subsection{Reverse Phase-High Pressure Liquid Chromatography}

Novel RP-HPLC methods were developed for RES and AJM and validated according to ICH guidelines [13]. HPLC was carried out in Dionex (Thermo scientific, New Delhi, India) system and analyzed by Chromeleon 6.8 chromatography data system software (Thermo scientific, New Delhi, India). The chromatographic conditions used for rapid and precise detection of the compounds are mentioned in Table 8. Parameters of validated method were calculated as linearity, precision, LOD, and LOQ.

Table 8. Chromatographic conditions for RES and AJM RP-HPLC method with UV detection.

\begin{tabular}{ccc}
\hline Variables & Conditions for RES & Conditions for AJM \\
\hline Absorbance maxima $(\lambda)$ & $260 \mathrm{~nm}$ & $268 \mathrm{~nm}$ \\
Column & Zorbax HPLC C $18(150 \mathrm{~mm} \times 4.6$ & Inertsil HPLC C $(250 \mathrm{~mm} \times 4.6$ \\
mom, i.d. $5 \mu \mathrm{m})$ \\
Mobile phase & mm, i.d. $5 \mu \mathrm{m})$ & Water:Acetonitrile $(30: 70 v / v)$ \\
Flow Rate & Water:Methanol $(20: 80 v / v)$ & $0.5 \mathrm{~mL} / \mathrm{min}$ \\
Injection volume & $1 \mathrm{~mL} / \mathrm{min}$ & $20 \mu \mathrm{l}$ \\
Elution & $10 \mu \mathrm{l}$ & Isocratic \\
\hline
\end{tabular}

RES and AJM present in R. serpentina extract were quantified from the pure standards (std) run under same chromatographic conditions.

Quantity $($ test $)=[$ Average area $($ test $) /$ Average area $($ Std $)] \times[$ weight $\cdot($ std $) /$ weight $\cdot($ test $)] \times$ Std purity $\%$ where average area is the chromatographic area under the peak for standard and test, weight is measured amount used to prepare dilution. 


\subsection{Preparation of A 442 Fibrils}

$44 \mu \mathrm{M}$ of $\mathrm{A} \beta 42$ was dissolved in milliQ water and mixed with various concentrations of compounds to study. A $\beta 42$ alone sample was used as control. Samples were incubated at $37^{\circ} \mathrm{C}$ at $260 \mathrm{rpm}$ for $48 \mathrm{~h}$ in the shaker incubator. Samples were taken out at their stipulated time interval and various experimentations (ThT-binding measurement, Congo red, CD spectra analysis, and TEM) were performed to study the inhibition of amyloid fibril formation by the compounds under study.

\subsection{ThT Fluorescence Spectroscopy Measurements}

A $\beta 42$ samples were incubated with or without compounds at different concentrations, after 48 $\mathrm{h}$ of fibril formation samples from each experimental set were withdrawn and mixed with ThT in opaque micro titer plate. The reactions were then incubated in dark at $37^{\circ} \mathrm{C}$ for $30 \mathrm{~min}$ for ThT probe to bind the formed amyloid fibrils. The ThT was excited at $450 \mathrm{~nm}$ and spectra were recorded from 400 to $650 \mathrm{~nm}$ [27]. All measurements were performed in triplicates and all experiments were repeated thrice individually.

\subsection{Congo Red Binding Assay}

Congo red $(200 \mu \mathrm{M})$ was dissolved in a $50 \mathrm{mM}$ phosphate buffer ( $\mathrm{pH} 7.4)$ consisting of $50 \mathrm{mM}$ $\mathrm{NaCl}$ and $10 \%$ ethanol and filtered through $0.45 \mu \mathrm{m}$ CA membrane filter. The $\mathrm{A} \beta 42$ concentration was fixed at $10 \mu \mathrm{M}$ in the reaction mixture. $\mathrm{CR}$ and protein were mixed at a molar ratio of 1:1 for various experimental setups and kept for $30 \mathrm{~min}$ incubation at room temperature. The absorbance spectra (400-650 nm) of the samples were recorded with a UV-visible spectrophotometer [27]. All experiments had three technological and three biological repeats.

\subsection{Circular Dichroism Spectroscopy}

Secondary structure of $A \beta 42$ peptides were recorded as far UV circular dichroism spectra using Chirascan (Applied PhotoPhysics, New Delhi, India) instrument and software. $22 \mu \mathrm{M}$ A $\beta 42$ samples ( $22 \mu \mathrm{M} A \beta 42$ alone and A $\beta 42$ with RES and AJM) were mixed well ensuring a homogenous suspension and transferred to quartz cell for CD spectra scanning. CD spectra was recorded from 200-260 nm at RT using a bandwidth of $1.0 \mathrm{~nm}$, times per point $0.5 \mathrm{sec}$, a step interval of $1 \mathrm{~nm}$, and $10 \mathrm{~mm}$ path length. Five scans of each sample were measured and averaged. Averaged control buffer scans were subtracted from the sample spectra. The results of CD measurement were plotted as graph between measured ellipticity (millidegree) and wavelength $(\mathrm{nm})$. The secondary structure contents ( $\alpha$-helix, $\beta$-sheet, turn, and random coil) of the $A \beta 42$ peptide samples were estimated from the CD spectra using the CD Pro software [20]. Relative percentage of reduced $\beta$-sheet content in $A \beta 42$ samples treated with RES and AJM was calculated using BeStSel software [28].

\subsection{Transmission Electron Microscopy}

$5 \mu \mathrm{L}$ A $\beta 42$ prepared fibril samples $(22 \mu \mathrm{M}) \mathrm{A} \beta 42$ alone and A $\beta 42$ with RES and AJM) were loaded on carbon stabilized, formvar coated grid for $40 \mathrm{sec}$. Ashless filter paper was used to wipe out extra sample from the edges of the grid. Loaded grid was negatively stained with $1 \%$ uranyl acetate for $20 \mathrm{sec}$ and air-dried. Grid was then examined and photographed on JEOL 2100F transmission electron microscope.

\subsection{Aß42 Induced Neurotoxicity in PC12 Cells}

Undifferentiated PC12 cell line used as an AD model to study neurotoxicity in the current study, was maintained as monolayer adherent cultures in RPMI 1640 medium supplemented with 5\% FBS and $1 \%$ antibiotic [29]. Cells were seeded in 96 well plate in log phase of growth at concentration $5 \times 10^{5}$ cells per well. Pre-incubation was given with homotaurine $(40 \mu \mathrm{M}$, as positive control), RES $(10,20,40 \mu \mathrm{M}), \operatorname{AJM}(10,20,40 \mu \mathrm{M})$, and R. serpentina extract $(25,50,100 \mu \mathrm{g} / \mathrm{mL})$. Cytotoxicity with 
preformed $\mathrm{A} \beta 42$ fibrils aged $48 \mathrm{~h}$ at $40 \mu \mathrm{M}$ ( $\mathrm{IC}_{50}$ value) was induced to compounds pre-acclimatized PC12 cells for $24 \mathrm{~h}$. MTT solution was added to the wells and incubated in dark, for the live cells to convert the tetrazolium salt in purple formazan crystals. The formazan crystals were dissolved using DMSO and absorbance was measured at $570 \mathrm{~nm}$. Relative survival percentage of PC12 cells was calculated compared to control (PC12 cells only). All measurements were performed in triplicates and all experiments were repeated thrice individually.

\subsection{Neuroprotection Against Oxidative Stress Cytotoxicity Using $\mathrm{H}_{2} \mathrm{O}_{2}$}

Oxidative stress was induced to cultured PC12 cells using hydrogen peroxide ( $\mathrm{IC}_{50} 200 \mu \mathrm{L}$ ) and concentrations of glutathione (positive control), RES, $\operatorname{AJM}(10,20,40 \mu \mathrm{M})$, and R. serpentina extract (25, $50,100 \mu \mathrm{g} / \mathrm{mL}$ ) were used to analyze neuroprotective effects against oxidative damage through MTT assay. Cell viability was determined through trypan blue dye exclusion assay and cells were seeded to 96 well tissue culture plate at a $5 \times 10^{5}$ cells/well concentration. Pre-incubation with compounds were given to PC12 cells prior to inducing $\mathrm{H}_{2} \mathrm{O}_{2}$ cytotoxicity for $18 \mathrm{~h}$. MTT was added to the well at $5 \mathrm{mg} / \mathrm{mL}$ concentration and incubated in the dark for enzymatic reaction by live cells for $2 \mathrm{~h}$. DMSO was added to well to dissolve formazan crystals and absorbance was recorded at $570 \mathrm{~nm}$. PC12 cells relative survival was calculated compared to control (PC12 cells only).

\subsection{In Vitro ChE Enzyme Assay}

Ellman assay was performed to assess the inhibition of the enzyme AChE (EC 3.1.1.7) and BuChE (EC 3.1.1.8) by donepezil (positive control), RES, AJM, and R. serpentina extract [30]. Five microliters of enzyme (AChE and $\mathrm{BuChE}$ ) solution at $0.03 \mathrm{U} / \mathrm{mL}$ final assay concentration; $200 \mu \mathrm{L}$ of phosphate buffer (pH 8); $5 \mu \mathrm{L}$ of DTNB ( $0.3 \mathrm{mM}$ ); and $5 \mu \mathrm{L}$ of test compounds were pre-incubated for $15 \mathrm{~min}$ at RT. The reaction was initiated by adding $5 \mu \mathrm{L}$ of substrate (ATChI and BuTChI) at a final concentration of $0.5 \mathrm{mM}$. The control for relative absorbance consisted of the buffer in place of the test compounds and the enzyme and substrate blank were devoid of enzyme and the substrate, respectively. Three biological and three experimental repeats were performed and read at $412 \mathrm{~nm}$ on a SpectraMax M2 reader.

\subsection{In Vitro BACE-1 Enzyme Inhibition Assay}

BACE-1 (EC 3.4.23.46) activity inhibition was assayed using FRET (fluorescence resonance energy transfer) kit (Sigma Aldrich, New Delhi, India). With all reaction components at RT, $50 \mu \mathrm{M}$ substrate was added to $75 \mu \mathrm{L}$ assay buffer containing RES and $\operatorname{AJM}(25,50,100 \mu \mathrm{M})$ in the microtiter plate. Reaction was initiated by the addition of $0.03 \mathrm{U}$ BACE-1 enzyme in the well and zero minute fluorescence was recorded (Ex $350 \mathrm{~nm}, \mathrm{Em} 405 \mathrm{~nm}$ ). After $2 \mathrm{~h}$ incubation in dark at $37^{\circ} \mathrm{C}$, reaction fluorescence was recorded every one hour for next three hours. Relative fluorescence inhibition was calculated from zero minute fluorescence reading as control. Three individual experiments were performed.

\subsection{Monoaminoxidase-B (MAO-B) Inhibition Assay}

MAO-B (EC 1.4.3.4) activity inhibition was assayed using Biovision inhibition screening kit (fluorometric). With all reaction components at room temperature, $0.2 \mathrm{U}$ enzyme was pre-incubated with compounds under study and incubated for $10 \mathrm{~min}$. Working substrate was prepared fresh by adding developer and oxired probe with assay buffer according to kit instructions. Substrate was added to the reaction and incubated for $10 \mathrm{~min}$; zero-minute fluorescence was recorded (Ex $535 \mathrm{~nm}$, Em $587 \mathrm{~nm}$ ) to serve as control for relative fluorescence inhibition calculation. All measurements were performed in triplicates and all experiments were repeated thrice individually.

\subsection{Molecular Docking Analysis by Autodock 4.2}

Molecular interactions of RES and AJM with selected AD targets (A $342, A C h E, B u C h E, B A C E-1$, and MAO-B) were studied using Autodock 4.2 [31]. Respective of good resolution, co-crystallized 
structures were procured from protein data bank (1YIT for A $\beta 42,4 \mathrm{PQE}$ for AChE, 2J4C for BuChE, 4D8C for BACE-1, and 1S2Q for MAO-B). Three-dimensional structures of RES and AJM and known inhibitors (galanthamine, tacrine, rasagilline, tannic acid, and BXD) were downloaded from Pubchem Database. Co-crystallized proteins were processed using PyMol to get the Apo structure of the protein and ligand in separate formats [32]. Re-docking was done with prepared co-crystalized ligand and prepared receptor protein to validate the docking protocol and the maps were generated. Root mean square deviation (RMSD) was calculated as a measure of legitimate docking protocol. Post validation of the docking protocol, RES and AJM processed ligand structures were individually docked with target receptor proteins in the study. Molecular interactions, ligand conformations, and binding energies were obtained.

\subsection{Pharmacokinetic Analysis (ADMET)}

ADMET analysis was carried out using Drulito software (www.niper.gov.in/pi_dev_tools/ DruLiToWeb/DruLiTo_index.html) to study ideal pharmacokinetics profile of RES and AJM for drug development. Two filters were used for screening; Lipinski rule and blood brain barrier. Lipinski rule states that for an ideal drug molecule should weigh below $500 \mathrm{~g} / \mathrm{mol}$, hydrogen bond donor should be less than or equal to 5 and number of hydrogen bond acceptor should be less than or equal to 10 along with a partition coefficient of 5 or less. Such compounds would pass the BBB if the number of hydrogen bonds present is below eight and there should not be any acidic group present in the molecule. Total polar surface area (TPSA) showed bioavailability of the drug molecule as per Veber's rule the TPSA less than or equal to $140 \AA$ indicates good oral bioavailability.

\subsection{Statistical Analysis}

Three independent experiments and each experiment with three replicates, were used in each experimental setup to present data as mean \pm standard error mean but for LCMS data $n=4$ runs were used. Statistical analysis was performed using one-way ANOVA for comparing independent means, followed by Bonferroni post test for multiple comparisons of experimental setups with control groups. Level of significance was determined as $p \leq 0.05$ and $p<0.01$, until otherwise stated.

\section{Conclusions}

In conclusion, the novel study showed that RES and AJM could act as multi-target directed ligands and can be used to develop into novel compound that can be used against several targets $\mathrm{A} \beta 42, \mathrm{AChE}$, BuChE, MAO-B, BACE-1, and ROS that are implicated in AD and thus, help in alleviation of symptoms and having disease modifying effect in AD.

Author Contributions: Conceptualization, S.K.; methodology, P.K.; software, P.K.; validation, P.K., V.K. and R.K.; formal analysis, P.K. and S.K.; investigation, P.K. and S.K.; resources, S.K., V.K., R.K.; data curation, P.K., V.K., R.K.; writing - original draft preparation, S.K. and P.K.; writing—review and editing, S.K.; visualization, S.K. and P.K.; supervision, S.K.; project administration, S.K.; funding acquisition, S.K. All authors have read and agreed to the published version of the manuscript.

Funding: This work was supported by Faculty Research Grant Scheme (FRGS) of GGS Indraprastha University, New Delhi.

Acknowledgments: We wish to thank Manisha Niranjan and Shweta Trikha from Indian Pharmacoepia Commission for providing some LCMS standards needed in the study and their help in using LC-MS and HPLC facility at IPC.

Conflicts of Interest: The authors declare that they have no financial or non-financial competing interests.

\section{Abbreviations}

AD-Alzheimer's disease, RES-Reserpine, AJM-Ajmalicine, MTDL-Multi-target directed ligand, APP-Amyloid precursor protein, A $\beta 42-$ Amyloid beta 1-42 residues, AChE-Acetylcholinesterase, BuChE-Butyrylcholinesterase, MAO-B-Monoaminooxidase B, BACE1-Beta site cleaving enzyme 1(beta-secretase), ROS-Reactive oxygen species, CAS-Catalytic anionic site, PAS-Peripheral anionic 
site, LOD—Level of detection, LOQ-Level of quantification, UPLC—Ultra pressure liquid chromatography, QTOF-Quadrupole time of flight, HPLC - High pressure liquid chromatography, ThT_-Thioflavin T, CR-Congo Red, CD—Circular dichroism.

\section{References}

1. Price, M.; Comas-Herrera, A.; Knapp, M.; Guerchet, M.; Karagiannidou, M. World Alzheimer Report 2016 Improving Healthcare for People Living with Dementia. Available online: http://eprints.lse.ac.uk/67858 (accessed on 19 December 2019).

2. Wimo, A.; Guerchet, M.; Ali, G.C.; Wu, Y.T.; Prina, A.M.; Winblad, B.; Liu, Z.; Prince, M. The worldwide costs of dementia 2015 and comparisons with 2010. Alzheimer's Dement. 2017, 13, 1-7. [CrossRef] [PubMed]

3. Carrano, A.; Hoozemans, J.J.; Van der Vies, S.M.; Rozemuller, A.J.; Van Horssen, J.; De Vries, H.E. Amyloid beta induces oxidative stress-mediated blood-brain barrier changes in capillary amyloid angiopathy. Antioxid. redox Signal. 2011, 15, 1167-1178. [CrossRef] [PubMed]

4. Hardy, J.A.; Higgins, G.A. Alzheimer's disease: The amyloid cascade hypothesis. Science 1992, 256, 184-186. [CrossRef]

5. Hughes, R.E.; Nikolic, K.; Ramsay, R.R. One for all? Hitting multiple Alzheimer's disease targets with one drug. Front. Neurosci. 2016, 10, 177-187. [CrossRef]

6. Melnikova, I. Therapies for Alzheimer's disease. Nat. Rev. Drug Discov. 2007, 6, 341-342. [CrossRef]

7. Pera, M.; Camps, P.; Munoz-Torrero, D.; Perez, B.; Badia, A.; Guillen, M.V. Undifferentiated and differentiated PC12 cells protected by huprines against injury induced by hydrogen peroxide. PLoS ONE 2013, 8, 1-8. [CrossRef]

8. Malagelada, C.; Greene, L.A. PC12 cells as a model for Parkinson's disease research. In Parkinson's Disease; Academic press: Cambridge, MA, USA, 2008; pp. 375-387.

9. Rungsung, W.; Dutta, S.; Mondal, D.N.; Ratha, K.K.; Hazra, J. Pharmacognostical Profiling on the Root of Rauwolfia serpentina. Int. J. Pharmacogn. Phytochem. Res. 2014, 6, 612-616.

10. Mittal, D.B.; Meenakshi, D.; Sharma, D.A.; Kumar, D.V. Phytochemical \& pharmacological activity of rauwolfia serpentina-a review. Int. J. Ayurvedic Herb. Med. 2012, 2, 118-130.

11. Luxenberg, J.; Feigenbaum, L.Z. The use of reserpine for elderly hypertensive patients. J. Am. Geriatr. Soc. 1983, 31, 556-559. [CrossRef]

12. Roberts, M.F. Alkaloids: Biochemistry, ecology, and medicinal applications; Springer Science \& Business Media: New York, NY, USA, 2013.

13. Guideline, I.H. Validation of Analytical Procedures: Text and Methodology Q2 (R1); International conference on harmonization: Geneva, Switzerland, 2005; pp. 11-12.

14. Hoyer, W.; Grönwall, C.; Jonsson, A.; Ståhl, S.; Härd, T. Stabilization of a $\beta$-hairpin in monomeric Alzheimer's amyloid- $\beta$ peptide inhibits amyloid formation. Proc. Natl. Acad. Sci. USA 2008, 105, 5099-5104. [CrossRef]

15. Westerink, R.H.; Ewing, A.G. The PC12 cell as model for neurosecretion. Acta Physiol. 2008, 192, $273-285$. [CrossRef] [PubMed]

16. Roberds, S.L.; Anderson, J.; Basi, G.; Bienkowski, M.J.; Branstetter, D.G.; Chen, K.S.; Freedman, S.; Frigon, N.L.; Games, D.; Hu, K.; et al. BACE knockout mice are healthy despite lacking the primary $\beta$-secretase activity in brain: Implications for Alzheimer's disease therapeutics. Hum. Mol. Genet. 2001, 10, 1317-1324. [CrossRef] [PubMed]

17. Merlini, G.; Bellotti, V. Molecular mechanisms of amyloidosis. New Engl. J. Med. 2003, 349, 583-596. [CrossRef] [PubMed]

18. Hardy, J. Alzheimer's disease: The amyloid cascade hypothesis: An update and reappraisal. J. Alzheimer's Dis. 2006, 9, 151-153. [CrossRef] [PubMed]

19. Ng, Y.P.; Or, T.C.; Ip, N.Y. Plant alkaloids as drug leads for Alzheimer's disease. Neurochem. Int. 2015, 89, 260-270. [CrossRef]

20. Sagi, S.; Avula, B.; Wang, Y.H.; Khan, I.A. Quantification and characterization of alkaloids from roots of Rauwolfia serpentina using ultra-high performance liquid chromatography-photo diode array-mass spectrometry. Anal. Bioanal. Chem. 2016, 408, 177-190. [CrossRef] 
21. Srivastava, A.; Tripathi, A.K.; Pandey, R.; Verma, R.K.; Gupta, M.M. Quantitative determination of reserpine, ajmaline, and ajmalicine in Rauvolfia serpentina by reversed-phase high-performance liquid chromatography. J. Chromatogr. Sci. 2006, 44,557-560. [CrossRef]

22. Du, Y.; Feng, M.; Wang, Y.N.; Cheng, L.; Wang, M.; Zhao, C.J. Simultaneous Determination of Reserpine, Yohimbine and Ajmalicine in the Extract of Rauvolfia Rootstocks, Branches and Leaves by HPLC. Asian J. Chem. 2014, 26, 7245-7248. [CrossRef]

23. Urbanc, B.; Betnel, M.; Cruz, L.; Bitan, G.; Teplow, D.B. Elucidation of amyloid $\beta$-protein oligomerization mechanisms: Discrete molecular dynamics study. J. Am. Chem. Soc. 2010, 132, 4266-4280. [CrossRef]

24. Micsonai, A.; Wien, F.; Kernya, L.; Lee, Y.H.; Goto, Y.; Réfrégiers, M. Accurate secondary structure prediction and fold recognition for circular dichroism spectroscopy. Proc. Natl. Acad. Sci. USA 2015, 112, 3095-3103. [CrossRef]

25. Lan, J.S.; Xie, S.S.; Li, S.Y.; Pan, L.F.; Wang, X.B.; Kong, L.Y. Design, synthesis and evaluation of novel tacrine-( $\beta$-carboline) hybrids as multifunctional agents for the treatment of Alzheimer's disease. Bioorganic Med. Chem. 2014, 22, 6089-6104. [CrossRef] [PubMed]

26. Schultz, A.W.; Wang, J.; Zhu, Z.J.; Johnson, C.H.; Patti, G.J.; Siuzdak, G. Liquid chromatography quadrupole time-of-flight characterization of metabolites guided by the METLIN database. Nat. Protoc. 2013, 8, 451-460.

27. Kashyap, P.; Muthusamy, K.; Niranjan, M.; Trikha, S.; Kumar, S. Sarsasapogenin: A steroidal saponin from Asparagus racemosus as multi target directed ligand in Alzheimer's Disease. Steroids 2020, 153, 108529. [CrossRef] [PubMed]

28. Micsonai, A.; Wien, F.; Bulyáki, É.; Kun, J.; Moussong, É.; Lee, Y.H. BeStSel: A web server for accurate protein secondary structure prediction and fold recognition from the circular dichroism spectra. Nucleic Acids Res. 2018, 46, 315-322. [CrossRef] [PubMed]

29. Shafer, T.J.; Atchison, W.D. Transmitter, ion channel and receptor properties of pheochromocytoma (PC12) cells: A model for neurotoxicological studies. Neurotoxicology 1991, 12, 473-492. [PubMed]

30. Kumar, S.; Seal, C.J.; Okello, E.J. Kinetics of acetylcholinesterase inhibition by an aqueous extract of Withania somnifera roots. Int. J. Pharm. Sci. Res. 2011, 2, 1188-1192.

31. Morris, G.M.; Huey, R.; Lindstrom, W.; Sanner, M.F.; Belew, R.K.; Goodsell, D.S. AutoDock4 and AutoDockTools4: Automated docking with selective receptor flexibility. J. Comput. Chem. 2009, 30, 2785-2791. [CrossRef]

32. DeLano, W.L. Pymol: An open-source molecular graphics tool. CCP4 Newsl. Protein Crystallogr. 2002, 40, $82-92$.

Sample Availability: Samples of the compounds are available from Sigma Aldrich.

(C) 2020 by the authors. Licensee MDPI, Basel, Switzerland. This article is an open access article distributed under the terms and conditions of the Creative Commons Attribution (CC BY) license (http://creativecommons.org/licenses/by/4.0/). 